CHAPTER 8

\title{
Encounters with the Past
}

\section{Fractals and Atmospheres at Kasuga Wakamiya Onmatsuri}

\author{
Andrea Giolai \\ Leiden University, Leiden, The Netherlands \\ a.giolai@hum.leidenuniv.nl
}

\begin{abstract}
Kasuga Wakamiya Onmatsuri is an important local festival celebrated every winter in Nara. While the festival has been analyzed from the point of view of its relations with religious institutions such as Kasuga Taisha and Kōfukuji, to date less attention has been paid to its historical transformations. Countering linear narratives that tend to portray it as largely unchanged since its inception, this chapter combines ethnography, historiography, and religious studies to provide a more multivocal analysis of the Onmatsuri. After an overview of its main celebrations, the chapter revisits the origins of the festival, describes the ontological multiplicity of its deities, and analyzes material elements that concur to its "fractal" features. Showing how these heterogeneous elements generate a diffuse "atmosphere of the past," this study discusses practitioners' accounts of ritual participation, as well as the relationship between ideological reconstructions of the past and material embodiments of religious symbols.
\end{abstract}

\section{Keywords}

Kasuga Wakamiya Onmatsuri - Nara - gagaku - material religion - atmosphere

\section{$1 \quad$ Introduction}

Every December, the amateur group Nanto Gakuso 南都楽所 takes part in Nara's Kasuga Wakamiya Onmatsuri 春日若宮おん祭, a large festival familiarly known as "Onmatsuri" or simply "the matsuri." Throughout its celebrations,

$1 O n$-is an alternative reading of the honorific character 御. Sources up to the encyclopaedic

(C) ANDREA GIOLAI, 2020 | DOI:10.1163/9789004466548_009

This is an open access chapter distributed under the terms of the CC BY-NC 4.o license 4 rea Giolai - 9789004466548 
and especially during the 24 hours between 16 December and 17 December, members of Nanto Gakuso perform numerous gagaku 雅楽 and bugaku 舞楽 pieces, elegant music and dances for which Onmatsuri is especially renowned. ${ }^{2}$ Given its long history, religious contents, and demanding performances, the festival is construed as crucial to the group's identity, and participation as both a great privilege and the ultimate reward for months of rehearsals. During my fieldwork with them, I was struck by how the musicians and dancers of Nanto Gakuso described the matsuri in connection to its distinctive "atmosphere." In conversation, practitioners alluded to marked dissimilarities between indoor events, such as stage concerts, and outdoor celebrations, like matsuri and Buddhist services. While the former were seen merely as vehicles of artistic expression, the latter were for them more intense experiences, hardly captured by expressions like "concert" (ensō 演奏) or "performance" ( jōen 上演).

Indeed, as pointed out by my interlocutors, playing at matsuri requires a particular affective disposition, one that must be consonant with the specific ritual and religious overtones of the event. ${ }^{3}$ In this context, the concept of "the matsuri atmosphere" (matsuri no fun'iki 祭りの雾囲気) emerged as a powerful emic trope used to describe sensations prevalent in moments of intense par-

Kojiruien 古事類苑 (1896-1914) refer to the festival as gosairei 御祭礼 or Kasuga Wakamiya $s a i$ 春日若宮祭. It is unclear when the term Onmatsuri first came into use. For a general overview of Japanese matsuri that assumes "universal features common to traditional rituals in general," see Plutschow (1996). For a more nuanced approach, see Hardacre (2017: 475507). Hardacre is fully aware of the treacherous task of defining matsuri: she notes that the term "can be used in a broad sense to denote any shrine observance of a celebratory nature," but adds that it may also have "vernacular meanings that include festival but also transcend the boundaries of the term's usage in academic Shinto circles" (Hardacre 2017: 477).

2 The characters that make up the word gagaku are often translated as "Japanese court music," but a more accurate rendition would be "elegant (雅) music-and-dance (楽)" (see Endō 2013). Today, gagaku is a Japanese traditional performing art consisting of accompanied vocal compositions, purely instrumental compositions, and compositions that accompany dance. The melodies were either borrowed from the Asian continent between the seventh and eighth century CE, then modified in Japan, or composed anew by Japanese authors during the Heian and Kamakura periods (see Nelson 2008; Terauchi 2016). Gagaku has been a part of Shintō and Buddhist ceremonies from its inception; today, it is often performed during rites of passage such as marriages and funerals. The genre is intimately associated with the Imperial court and stately protocol, conveying sentiments of solemnity and an aura of antiquity. Apart from the Onmatsuri, another important local celebration that features a large number of bugaku pieces is the Shōryōe bugaku daihōyō 聖霊会舞楽大法要, which takes place on 22 April at Shitennōji 四天王寺 temple in Osaka, as a memorial service for Prince Shōtoku (see Minamitani 2008; Terauchi 2013).

3 Significantly, the verb most commonly used to describe gagaku and bugaku performances at the Onmatsuri is the religiously inflected hōnō suru 奉納する, to “offer" or “dedicate" something to the kami. 
ticipation. Emanating from a heterogeneous network of material and immaterial elements-including sounds and gestures, but also animals, clothes, foods and even smells-the matsuri atmosphere was central to my interlocutors, yet peculiarly elusive. While putting fun'iki into words seemed at times like an impossible task, frequent references to the history and religious context of the matsuri made it abundantly clear that historical and religious concerns were central to my interlocutors. Historical, religious, and artistic facets of local matsuri are all staples of Japanese cultural anthropology, as evidenced by the pioneering work of Yanagita Kunio 柳田國男, Orikuchi Shinobu 折口信夫, and Honda Yasuji 本田安次. Yet, these studies tend to treat each of these aspects independently, maintaining a rigid separation between large-scale analyses and ethnographic examples of contemporary ritual participation.

In this chapter, I take a different approach, linking Onmatsuri's religious contents and convoluted history to the theoretical notions of "fractals" and "atmospheres." I mobilize the geometrical-turned-anthropological metaphor of the fractal not as an illustration of the matsuri's postmodern fragmentation, ${ }^{4}$ but because the complex part-whole relationship it evokes resonates with the tension between the phenomenological "figure" of ritual participation (i.e., a focus on certain "parts" of the matsuri), and its broader historical "ground" (i.e., the matsuri considered "as a whole"). Similarly, I relate the notion of "atmosphere" - increasingly popular in anthropology and ethnomusicologyto sketches from my fieldwork. ${ }^{5}$ Despite being central to its practitioners, moments of intense "atmospheric attunement" (Stewart 2011) often go unregistered in linear narratives of the Onmatsuri. ${ }^{6}$ Providing a multivocal description of the festival, I suggest that its longevity and ritual efficacy rest upon the diffused circulation of specific atmospheres of the past couched in apparently minor, easily overlooked moments of participation. Through a first-person account, I show how and why specific events in the festival came to be constructed in the current way, arguing that fractal participation and atmospheric attunement characterize contemporary participation in the Onmatsuri.

4 For an early "postmodernist view" of ritual, see Gerholm (1988).

5 For recent works on "atmosphere," see for example, Anderson (2009); Roquet (2016); Eisenlohr (2018); Slaby and Scheve (2019); Riedel and Torvinen (2019).

6 Terauchi (2011: 62-95) is a rare exception. Stewart (2011:452) rearticulates the contours of the term "atmosphere" noting that it points toward "an attunement of the senses, of labors, and imaginaries to potential ways of living in or living through things." I use the notion in a similar manner. 


\section{$1.1 \quad$ Otabishosai Fieldnotes, 16-17 December 2018}

I am sitting in a warm and loud dining hall full of people dressed in purple, green, and white costumes. It's almost 8pm, and soon the kitchen will close. The clothes I'm wearing are not my ordinary clothes: long, traditional hakama pants, a sleeved jacket with delicate patterns of purple wisteria flowers ( $f u j i$ ), and a stiff, hexagonal black hat. It's the ceremonial attire of my gagaku group, Nanto Gakuso, and the flowers are more than ornamental; as symbols of the Fujiwara house, they evoke the connection between the elegant music and dances of the "southern capital" (Nanto) and the Fujiwara, the most powerful family of premodern Japan. Though the situation is common enough (everyone around me is either having dinner or taking a break), the myriad symbols surrounding us-like the wisteria flowers on my clothes-situate the event in a historical framework, activating the powerful category of the past. As more members of the group flock in, the fabrics start to sway and whirl around in a colorful dance. I-san, a younger-looking man in his fifties, and F-san, a tall woman in her early sixties with a stern look neutralized by rare but broad smiles, are sitting across from me, and we are deep in conversation. I-san is getting excited, and F-san, cheeks now turning red, is listening with her eyes shut. "What do I like about this matsuri? Well, first of all, it's all about its atmosphere." Here, I-san inserts a long pause, for effect. "In other words," he resumes, "we come every year, we play for hours and hours, three days in a row; it's cold and you have to play flute, dance, sing, play drums ... it's exhausting! But if you think of the audience (okyakusan お客さん), when they're out there, and all they hear is the sounds coming from the forest, closer and closer ... then after a while they finally see the whole procession coming down, and the sound of gagaku gets louder and louder ..." F-san jumps in: "It's great!" "Right? Yeah, quite amazing" I-san resumes. "So, we are a big part of the matsuri. Actually, I think we are an indispensable part of the matsuri. Because, in the end, without the sound of gagaku there would be no 'Onmatsuri atmosphere." Second pause for effect. "Now, please have another bowl of miso soup. It's getting cold outside!"

As I pour myself another bowl, my thoughts go back to the night before. I am standing with the crowd in front of the temporary shrine, just $5^{\circ}$ meters from the dining hall. It's late, cold, and rain is pouring down on us. About one hundred people have gathered, and we are waiting on both sides of a dirt road. For over an hour, we have been staring at the dark path leading to the Kasuga Shrine, two kilometers uphill in the forest. The Akatsukisai 暁祭, a ritual in which various blessed foods are presented to the kami, is about to begin. Suddenly, the rain stops. It must be around midnight when we are finally able to make out faint sounds in the distance. Ten minutes later, I can dis- 
tinguish the contours of two white figures walking down between the trees. Gradually, I realize that these ghostly visions are dragging torches of burning pine, charcoal leaving a red, glimmering trail behind. Their mouths are covered by white cloth, and they are followed by a procession of approximately 20 priests, also in white. At the end of the procession, musicians play gagaku while walking. People around me whisper impatiently. As the procession draws near, we are instructed to lower our heads and turn off all electronic devices: no recordings allowed. Suddenly, I realize that everyone around me is humming out a deep, droning sound: "Oooo-." Right at that moment, the airnot just my surroundings, but the medium of every vibration - feels different: denser and still, it's filled with sounds, the smell of burning pine, incense and sap.

The memory is still fresh, but I am back in the dining hall, staring into my miso soup: "The Onmatsuri atmosphere, indeed!" I think, suspended between the silence of my interlocutors, the noises of the cafeteria, and the fleeting yet lingering impressions from the day before.

\section{From Linear Narratives to Fractal Accounts}

Rooted in ancient combinatory cults but firmly tied to Shintō in modern times, Nara's Onmatsuri lies at the intersection of spirituality, local identity, and touristic commodification. ${ }^{7}$ Today, the festival is one and many things: an important winter celebration with a history that goes back more than 800 years; a "living museum" of medieval performing arts (Misumi 1982: 66); an item of Japanese intangible cultural heritage; an economic asset capable of attracting swarms of tourists; and a source of public recognition and visibility for the city of Nara. Like many shrine celebrations, it is both secretive and bombastic, structured and chaotic, intensely numinous and utterly quotidian. ${ }^{8}$

To a casual bystander, however, Onmatsuri may appear not as a totality, but as a compilation of disjointed events. Two amateur photographers observing the horses gathered at the outer edge of Nara Park on the morning of 17 December 2018 , for example, seemed only superficially acquainted with the history

7 For a recent account that weaves together all three aspects, see Hatakama and Yasuda (2016).

8 For rare ethnographic analyses of Japanese festivals in English, see Ashkenazi (1994); Foster (2015); Kalland (1995); Schnell (1999). 


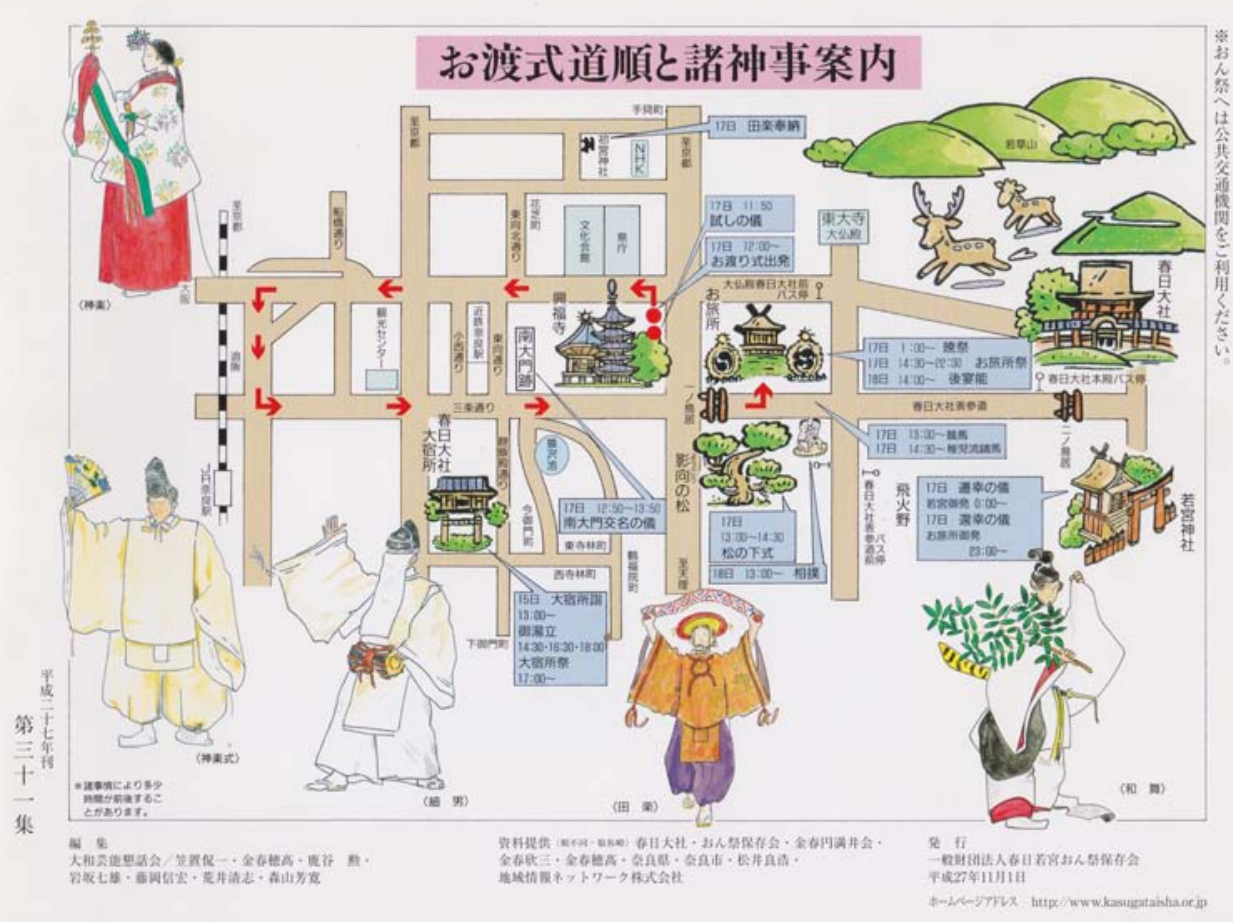

FIGURE 8.1 Map of the main events of 15-18 December. The title reads "Route of the Parade and Guide to Various Shintō Celebrations." Printed at the back of an information pamphlet compiled by the Association for the Preservation of the Ancient Arts of Kasuga and sold every year during the festival YAMATO GEINŌ KONWAKAI 2015

and ritual contents of the festival: "Me, I just came for the horses ... Did you know they bring them from all over Japan? They're gorgeous," said one of them, a man in his sixties. Nodding approvingly, the second man, somewhat older and with a thick Kansai accent, turned to me and added: "It's a very ancient festival, you know? Unchanged for a thousand years, or so I heard. They sell pamphlets with all the information, I think." Numerous examples of such casual conversations suggest that many people who attend the matsuri have only a general sense of its busy schedule (Fig. 8.1). For most of them, 17 December stands out as a particularly busy day, and can be considered a "matsuri within the matsuri." Thousands of visitors come only for the day, eager to watch a massive costume parade (owatari shiki 御渡り式) proceed through the central streets of Nara (Fig. 8.2).

For those interested in the artistic and ritual aspects of the matsuri, however, it is only after the parade, in the afternoon of 17 December, that the "Onmatsuri 


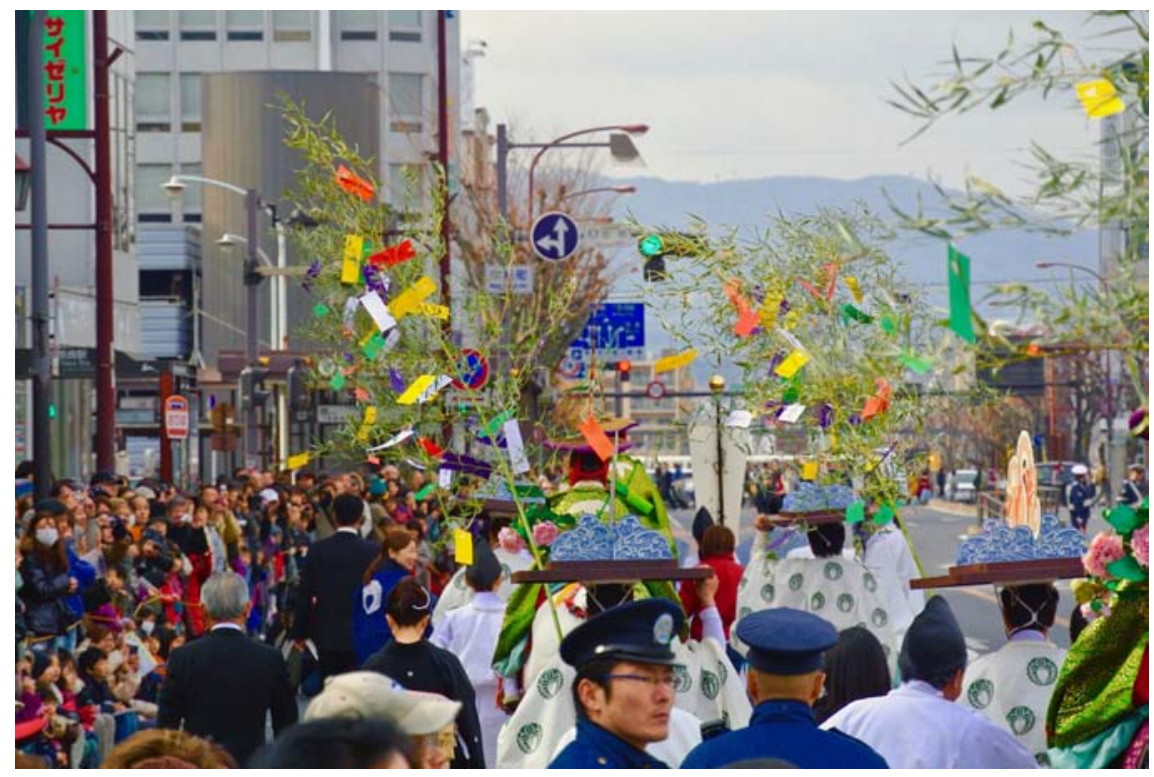

FIGURE 8.2 A detail of the Watarishiki parade. Citizens and tourists often follow the parade through the streets of Nara, showing support for friends or members of specific sectors $(z a)$, such as the dengaku troupe and the horseback archers. 17 December 2013

РНОTO BY AUTHOR

atmosphere" can be savored. Having kicked off at noon, the parade reaches the forested area of Kasuga Taisha 春日大社 by 2:oo pm. Following a series of ceremonial performances in front of an ancient pine tree (matsu no shita shiki 松 の下式), the participants enter a broad mossy area. Temporary wooden structures are set up to host musicians, priests and special guests overlooking a simple open-air stage (shiba butai 芝舞台) at the center of a stretch of land. At 4:Oo pm, music and dances are offered to the kami of Wakamiya Jinja 若宮 神社, who is hosted for 24 hours in a temporary dwelling place called angu $\bar{u}$ 行 宮 or kari no miya 仮宮 (Fig. 8.3). The kami has been brought down from its usual abode by means of an intense procession, called Senkō no Gi 遷幸の儀, on the night of 16 December (Fig. 8.4). During the procession, priests dressed in white transfer the body of the kami and intone the keihitsu警踶, a low, droning vocal sound that blends with gagaku creating an otherworldly "symphony" (Hashimoto 1986: 65). This is the moment I-san was referring to during our chat in the dining hall on 17 December, pointing toward its "atmospheric" quality.

The celebrations that start at 4:0o pm are known collectively as Otabishosai お旅所祭. They consist of a long succession of ancient performing arts, some of which are only performed in Nara. Gagaku and its danced repertoire, bugaku, 


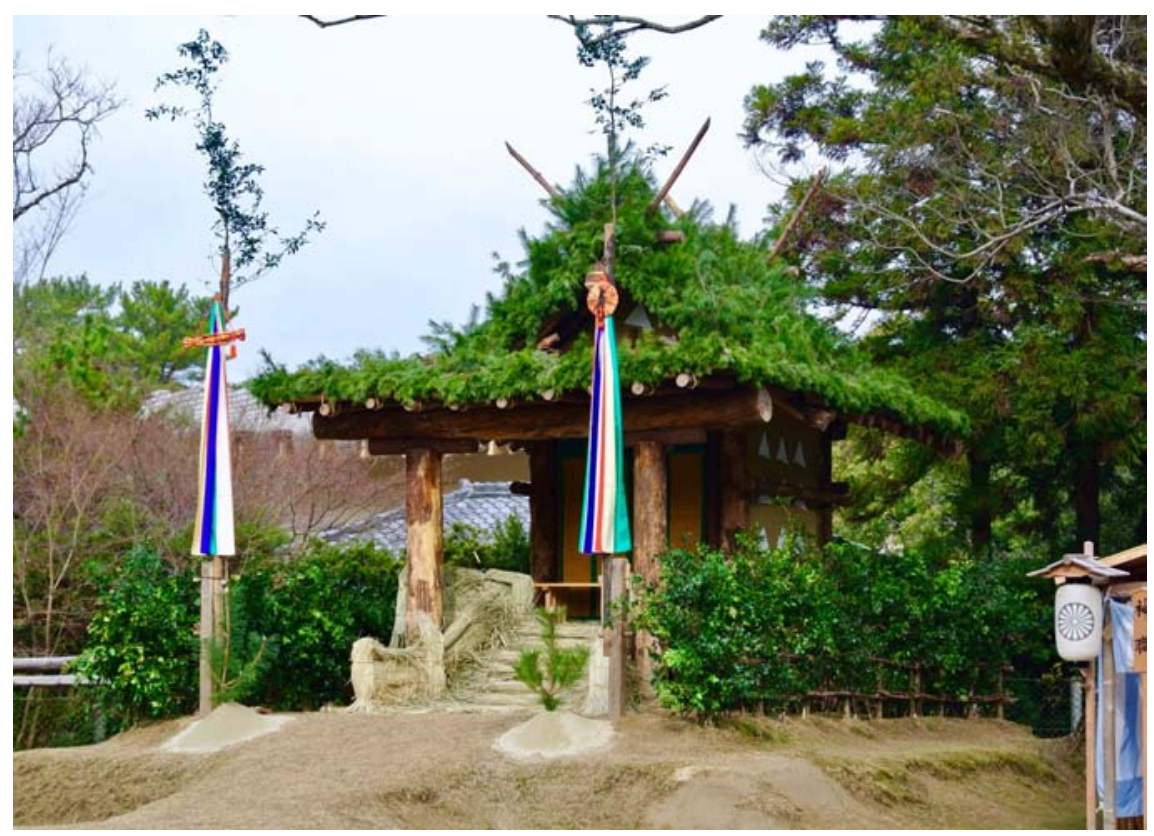

FIGURE 8.3 The angū or temporary shrine. Its rustic architectonic structure includes highly symbolic features, such as the white, triangular paper blocks on the walls: the origin of these decorative elements is still unclear. 17 December 2018 Pното BY AUTHOR

occupy a special role in the Otabishosai, with more than ten dances performed by Nanto Gakuso. At approximately 11:0o pm, all the lights are put out, the shintai $i$ 神体 is carefully removed, and the kami is brought back to Wakamiya Jinja, a shrine located on the East side of Kasuga Taisha's main pavilion. This procession, called Kankō no Gi 還幸の儀, mirrors the earlier Senkō no Gi of 16 December. It reaches the shrine just before midnight, and only musicians and shrine personnel are allowed to witness this section of the ritual. The Otabishosai then comes to a close, with a final dance performed by shrine priestesses, followed by the recitation of norito 祝詞 (prayers) reporting the successful conclusion of this year's celebrations and praying for the next. The scope and scale of Onmatsuri in general and of the Otabishosai in particular are uncommon for a local festival. A description of the events of 16 and 17 December may serve to illustrate the seamless interconnection of ritual moments that, although nested within the larger framework of the Onmatsuri, can also be experienced independently as instances of its general atmosphere. As I show below, multiple connections between its parts compose Onmatsuri's richly layered ritual participation. 
TABLE 1 Prospect of Onmatsuri's celebrations

\begin{tabular}{|c|c|c|}
\hline Day and time & Event & Overview \\
\hline 1 July & $\begin{array}{l}\text { Yabusame sadame } \\
\text { 流鏑馬定 }\end{array}$ & $\begin{array}{l}\text { In what can be considered the festival's first ceremony, } \\
\text { the groups in charge of organizing the horseback } \\
\text { archery announce to the kami of the Wakamiya Shrine } \\
\text { the names of the young boys who will be riding the } \\
\text { horses and shooting ceremonial arrows in the coming } \\
\text { festival (chigo 稚児). }\end{array}$ \\
\hline 1 October & $\begin{array}{l}\text { Nawamunesai } \\
\text { 縄棟祭 }\end{array}$ & $\begin{array}{l}\text { Purification of the area where the temporary shrine } \\
\text { will be built. }\end{array}$ \\
\hline $\begin{array}{l}\text { Beginning of } \\
\text { December }\end{array}$ & $\begin{array}{l}\text { Bachō no chigo no oku- } \\
\text { raiuke } \\
\text { 馬長児僧位僧官授写式 }\end{array}$ & $\begin{array}{l}\text { The boys who will serve as chigo go to Kōfukuji and } \\
\text { receive the official title of hōingon no daisōsu 法印 } \\
\text { 権大僧都, which only lasts for the duration of the } \\
\text { festival. }\end{array}$ \\
\hline 15 December 2:30 pm & Ōshukushosai 大宿所祭 & $\begin{array}{l}\text { Blessing of ritual offerings (wild game, fish, spears, } \\
\text { swords and armors). }\end{array}$ \\
\hline 16 December 2:3opm & Yoimiya mōde 宵宮詣 & $\begin{array}{l}\text { Visit to the Wakamiya Shrine, including several perfor- } \\
\text { mances. }\end{array}$ \\
\hline 4:0o pm & Yoimiyasai 宵宮祭 & $\begin{array}{l}\text { The Evening Rite of the Sacred Abode precedes the } \\
\text { removal of the kami's "body" (shintai) from its usual } \\
\text { abode. }\end{array}$ \\
\hline 10:30 pm & Senkōno gi 遷幸の儀 & $\begin{array}{l}\text { The body of the deity is transported to the temporary } \\
\text { shrine (otabisho). }\end{array}$ \\
\hline 17 December 1:0o am & Akatsukisai 暁祭 & Blessed offerings of food are presented to the deity. \\
\hline 9:0o am & Hondensai 本殿祭 & $\begin{array}{l}\text { Shrine priests visit both Kasuga Taisha and Wakamiya } \\
\text { Jinja. }\end{array}$ \\
\hline 12:0o pm & Owatari shiki お渡り式 & $\begin{array}{l}\text { A huge ceremonial parade featuring participants } \\
\text { dressed in ancient attire. The parade is divided into } \\
\text { twelve sectors ( } z a \text { 座): 1. Hi no tsukai 日使, the festi- } \\
\text { val's main sponsor; } 2 \text {. Miko 巫女, shrine priestesses; } \\
\text { 3-5. Performers of Seinō 細男, Sarugaku 猿楽 and } \\
\text { Dengaku 田楽; } 6-9 \text {. Participants in horseback archery } \\
\text { and ceremonial races; 10. Nodachihoka 野太刀, a dis- } \\
\text { play of special swords; 11. Yamatozamurai 大和士, } \\
\text { delegations of various local groups and corporations; } \\
\text { 12. Daimyō gyōretsu 大名行列, delegations from for- } \\
\text { mer domains (han 藩). }\end{array}$ \\
\hline 12:5० pm & $\begin{array}{l}\text { Nandaimon gyōmyō no gi } \\
\text { 南大門交名儀 }\end{array}$ & $\begin{array}{l}\text { Since Köfukuji monks were once among the main } \\
\text { organizers of the festival, the ceremonial parade used } \\
\text { to pass through the Southern Gate (nandaimon) of the } \\
\text { temple on its way to the temporary shrine. The monks } \\
\text { would then preside over the parade, announcing the } \\
\text { name of each sector and making sure that everything } \\
\text { was in order. Today, a similar ceremony is held, with a } \\
\text { symbolic function. }\end{array}$ \\
\hline
\end{tabular}


TABLE 1 Prospect of Onmatsuri's celebrations (cont.)

\begin{tabular}{|c|c|c|}
\hline Day and time & Event & Overview \\
\hline 1:0opm & $\begin{array}{l}\text { Matsu no shita shiki } \\
\text { 松の下式 }\end{array}$ & $\begin{array}{l}\text { Various performances are offered to the tutelary deity } \\
\text { of the medieval Kasuga-Kōfukuji multiplex. According } \\
\text { to legendary tales, the benevolent god Kasuga Daimyō- } \\
\text { jin 春日大明神 appeared beneath this sacred pine } \\
\text { tree. }\end{array}$ \\
\hline 1:0o pm & Keiba 競馬 & $\begin{array}{l}\text { Ceremonial horse race held in the area between the } \\
\text { sacred pine and the temporary shrine. }\end{array}$ \\
\hline 2:30 pm & $\begin{array}{l}\text { Chigo yabusame } \\
\text { 稚児流鏑馬 }\end{array}$ & Archery on Horseback performed by three young boys. \\
\hline 2:30 pm & Otabishosai 御旅所祭 & $\begin{array}{l}\text { Performances offered to the kami on the lawn stage: } 1 . \\
\text { Kagura 神楽 (Mikomai 巫女舞): dances of the shrine } \\
\text { priestesses; 2. Azuma asobi 東遊: a regional dance } \\
\text { performed by youngsters; 3. Dengaku 田楽: ancient } \\
\text { performing art connected to and evoking rice plant- } \\
\text { ing; } 4 \text {. Seinōo 細男: little is known about this simple } \\
\text { ritualistic dance, perhaps the vestige of a pantomime; } \\
\text { 5. Kagura shiki 神楽式 (also known as Sarugaku no } \\
\text { okinamai 猿楽の翁舞): a reconstructed version of the } \\
\text { precursor to Nō theater; 6. Bugaku舞楽: a uniquely } \\
\text { rich array of court music and dances including twelve } \\
\text { pieces, for a total of over five hours. The pieces per- } \\
\text { formed are: Enbu 振鉾; Manzairaku 万歳楽; Engiraku } \\
\text { 延喜楽; Katen 賀殿; Chikyu 地久; Yamatomai 大和 } \\
\text { 舞; Ran'ryōo 蘭陵王; Nasori 納曾利; Sanju 散手; } \\
\text { Kitoku 貴徳; Batō 抜頭; Rakuson 落蹲. }\end{array}$ \\
\hline 11:30 pm & Kankōno gi 還幸の儀 & $\begin{array}{l}\text { Symmetrical to the Senkō no gi, it consists in the } \\
\text { removal of the deity from the temporary shrine and } \\
\text { its transportation back to the Wakamiya Shrine. }\end{array}$ \\
\hline 18 December 1:oo pm & Hōnōzumōo 奉納相撲 & $\begin{array}{l}\text { Ceremonial sumo match performed by children and } \\
\text { adolescents. }\end{array}$ \\
\hline 2:0opm & Goen $N \bar{o}$ 後宴能 & $\begin{array}{l}\text { Nō performance on the lawn stage of the temporary } \\
\text { shrine. It marks the conclusion of the entire festival. }\end{array}$ \\
\hline
\end{tabular}

In the past 50 years, scholars have produced detailed and lengthy accounts of Onmatsuri's celebrations, often under the auspices of Kasuga Taisha. ${ }^{9}$ Japanese researchers often emphasize the festival's complexity: Ishii Tatsurō, for exam-

9 See especially Orikuchi (1967); Kasuga Kogaku Hozonkai (1982); Hashimoto (1986); Nagashima et al. (1991); Yamamichi (1991); Terauchi (2011: 61-95); Hatakama and Yasuda (2016). For an excellent visual documentation, see the 1991 Heibonsha documentary Chüsei no sairei: Chūo kara chihōe $e$ 中世の祭礼-中央から地方一. 
ple, notes that Onmatsuri is "a giant annual festival ... so complicated that one has to see it several times in order to understand it properly" (Ishii 1987: 134, 136). Overwhelmingly, analytical responses to this complexity have taken the form of meticulous descriptions of "ritual procedures" (shidai 次第), often accompanied by impersonal explanations of each component (see Tab. 1). In contrast, the limited academic literature available in English has tended to focus either on the symbiotic relationship between the festival and Yamato province at the time of Onmatsuri's inception, or on the cult of Kasuga Daimyōjin 春日大明神, a composite deity which originated at the Kasuga TaishaKōfukuji 興福寺 "shrine-temple multiplex" (jisha 寺社), the main "unified Shinto-Buddhist complex center" of medieval Nara (Grapard 1992:1).

In his monograph devoted to the religious center, Allan Grapard outlined the significance of the Onmatsuri as a moment of "regeneration" for the entire province of Yamato. According to his structuralist interpretation, "the symbolic body and the identity of the province are regenerated through an interaction of the binary opposition nature/culture that is expressed in food systems, dances, and games, all of which are subsumed under an opposition between purity and pollution that is at the foundation of the social hierarchy" (Grapard 1992: 167). ${ }^{10}$ While Grapard's analysis highlights how religious dynamics are articulated on a geographically vast scale, others have chosen to explore how the same processes have been represented through artistic iconography. ${ }^{11}$ Here, a special place is granted to the seemingly ubiquitous depictions of Kasuga Daimyōjin (also known as Kasuga Gongen 春日権現), the combinatory deity that emerged as the summation of the kami and buddhas venerated at the multiplex. The Kasuga Gongen genki 春日権現験記, a medieval set of illustrated scrolls, contains miraculous legends associated with the deity, and is arguably the most significant source of information on its cult (see Tyler 1990; Hardacre 2017: 190193)..$^{12}$

In all these examples, Onmatsuri is treated merely as a tile within a much larger mosaic. The only study in English devoted specifically to the festival is a journal article by Ishii Tatsurō (1987). Despite offering scant ethnographic details, Ishii's article shifts the focus from broad historical examinations to the

10 Similarly, Helen Hardacre recently noticed that the festival "projects an image of the unity, not only of the two institutions [of Kōfukuji and Kasuga Shrine], but also the city of Nara where they are located, and beyond its boundaries to encompass the entire province" (Hardacre 2017: 185).

11 See especially Susan C. Tyler (1992).

12 For a recent introduction, see the catalogue of the exhibition that commemorated the completion of its restoration (Kunaichō Sannomaru Shōzōkan 2018). 
festival's present format. This is a valuable contribution: with the exception of recent publications in Japanese (especially Terauchi 2011; Hatakama 2014; Hatakama and Yasuda 2016), research on Onmatsuri has been largely indifferent to the transformations, suppressions and reconstructions of the festival's constitutive elements, conveying the sense that little has changed between its inception in the twelfth century and the present. This has resulted in the lasting myth of Onmatsuri's unchanged iteration "for a thousand years," as stressed by casual spectators more interested in specific aspects of the event than in its religious or historical facets. But such "linear narratives" are at once simplistic and misleading. On the one hand, they often ignore or gloss over historical evidence that may call into question specific ideological accounts; on the other, they tend to portray ritual participation as an experientially flat act of impassive, external observation. To contrast such narratives, I propose to look at the "fractal elements" of Onmatsuri: those elements that break apart superficial coherences, bringing to light the dissonances and inconsistencies of Onmatsuri's linear accounts.

Originating from chaos theory, the term "fractal" "refers to phenomena of 'self-similarity,' or the tendency of patterns or structures to recur on multiple levels or scales" (Mosko 2005: 24). Since the 1980s, the analogical image of the fractal has been used in anthropological texts by important representatives of the so-called "ontological turn" (see e.g. Wagner 1991; Strathern 2004). In their works, the fractal has been used to describe the self-similarity of abstract notions that stand in a part-whole relationship, such as "the individual" and "the collective."

In a more circumscribed sense, fractals have been recently evoked with reference to Japanese religious rituals. ${ }^{13}$ Discussing the Japanese "medieval esoteric episteme," Fabio Rambelli has noted that "esoteric Buddhism envisions the cosmos as a fractal structure, in which each phenomenon is 'formally' similar to all others and to the totality" (Rambelli 2013: 35, my emphasis). In the semiotic worldview of esoteric Buddhism, in fact, "each component of the mandalic cosmos is both related to any number of other entities and equivalent to the totality itself" (Rambelli 2013: 14). This "recursive cosmology" (Rambelli 2013: 35 ) is precisely the context in which Onmatsuri was born. From this point of view, therefore, the development of a fractal approach to the study of Japanese matsuri in general and Onmatsuri in particular seems in line with current developments in the study of Japanese religiosity.

13 For a short discussion of possible images employed to theorize ritual, including that of the fractal, see Grimes (2013: 181-182). 
At the same time, the use of the term "fractal" builds upon new understandings of the ontological status of medieval Japanese deities. For Bernard Faure, for instance, their "fractal nature ... reflects an essential, ontological multiplicity that cannot and should not be reduced to historical accidents" (Faure 2016: 16). The image of the fractal reveals its full analytical import when Faure's observations are brought to bear on the broader context of ritual participation in a specific matsuri. Using it to grasp more effectively how a local festival is experienced by some of its participants allows us to appreciate the value of its constitutive parts not only as reflections, but also as "iterations" of the matsuri as a whole. This fractal quality of matsuri can overcome historical inconsistencies and apparent contradictions between different elements of the same festival, helping us to understand ritual participation in less normative ways than are often dictated by rigid structures like official shidai.

In the next section, I explore how a fractal approach can be applied to the study of Onmatsuri's early history. Moving from an analysis of the earliest available sources, I show that the "origin story" upheld by linear narratives of the festival is the result of selective reinterpretations of the past, intended to conceal the generative role of Buddhist institutions in the early phases of the matsuri's existence. My analysis reveals the kind of "nestedness" that characterizes anthropological uses of the term "fractal." My argument is that through subsequent modifications, erasures and reinstatements, material-symbolic elements of the Onmatsuri have been folded into and encapsulated in specific aspects of the festival, so that access to any of these aspects simultaneously provides access to the large-scale dimension of the entire matsuri, in a complex interplay of parts and whole.

\section{More Than One History}

According to some of Onmatsuri's most important stakeholders, such as Kasuga Taisha and the Association for the Preservation of the Ancient Arts of Kasuga (Kasuga Kogaku Hozonkai 春日古楽保存会), in 2019 the festival has been held 880 times. ${ }^{14}$ Such claims are hardly surprising: since the nomination of "the performing arts and Shintō rites of Kasuga Wakamiya Onmatsuri" (Kasuga Wakamiya Onmatsuri shinji geinō 春日若宮おん祭神事芸能) as items

14 See e.g. http://www.koto-netpress.com/bookmark/onmatsuri/ (Accessed 20 February 2019). 
of Japanese "important intangible folk cultural property" ( jūyō mukei minzoku bunkazai 重要無形民俗文化財) in 1979, a process of "musealization" and "heritagization" of the matsuri has been greatly accelerated (Hatakama and Yasuda 2016: 177). ${ }^{15}$ Despite frequent claims to Onmatsuri's "unbroken tradition" by government officials (see e.g. Yamato Geinō Konwakai 2015: 2), however, the festival's continuity is contradicted by the earliest available historical records. ${ }^{16}$

The modern circulation of an "origin myth" reshaping the public image of the matsuri into a quintessentially "Shintō" celebration has played a central role in this process of heritagization. In its most common version, the story states that the Onmatsuri was initiated in 1136 by the kanpaku 関白 Fujiwara no Tadamichi 藤原忠通 (1097-1164) in an attempt to appease the deities that had brought floods and famine to the province. Tadamichi offered prayers to the "young deity" of Wakamiya and started the festival on the seventeenth day of the ninth month in the second year of the Hōen 保延 era (1136), (Ishii 1987: 134; see Hatakama and Yasuda 2016: $3-6,91-96) .{ }^{17}$ Emphasizing the virtuous intervention of a member of the Fujiwara family — the founders of the Kasuga Shrine in the eighth century - the story places the kami of Wakamiya at the center of a politico-religious network binding Shintō institutions to the territorial control of the Yamato province.

As recently pointed out by Hatakama Kazuhiro and Yasuda Tsuguo, however, the so-called "Tadamichi origin story" (Hatakama 2014: 372) has little historical grounding and appears to be a comparatively recent reinvention of the past (see especially Hatakama and Yasuda 2016:3-24). The first document claiming that Tadamichi was responsible for the creation of the festival is the Record of Kasuga Shrine (Kasuga jinja ki 春日神社記), dated 1611 (Hatakama 2014: 371372). The story spread quickly in the following centuries, with the help of popular books designed and published at least in part to incorporate and spread it. Texts like the Collection of Famous Places in the Southern Capital (Nanto

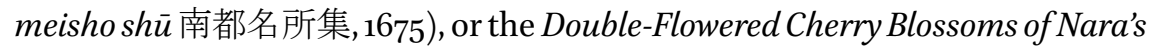
Famous Places (Nara meisho yaezakura 奈良名所八重桜, 1678), as well as the Annual Celebrations of Kasuga Shrine (Kasugasha nenjū gyōji 春日社年中行事,

\footnotetext{
15 On the history of intangible heritage preservation in Japan, see Akagawa (2015); Lancashire (2013); Thornbury (1997: 41-74).

16 Throughout the sixteenth century, for instance, the festival was repeatedly interrupted due to violent attacks by Yamato's neighboring samurai warlords (see Hatakama and Yasuda 2016: $75^{-76}$ ).

17 The following argumentation recapitulates arguments put forth by historians Hatakama Kazuhiro and Yasuda Tsuguo (see Hatakama 2014; Hatakama and Yasuda 2016).
} 


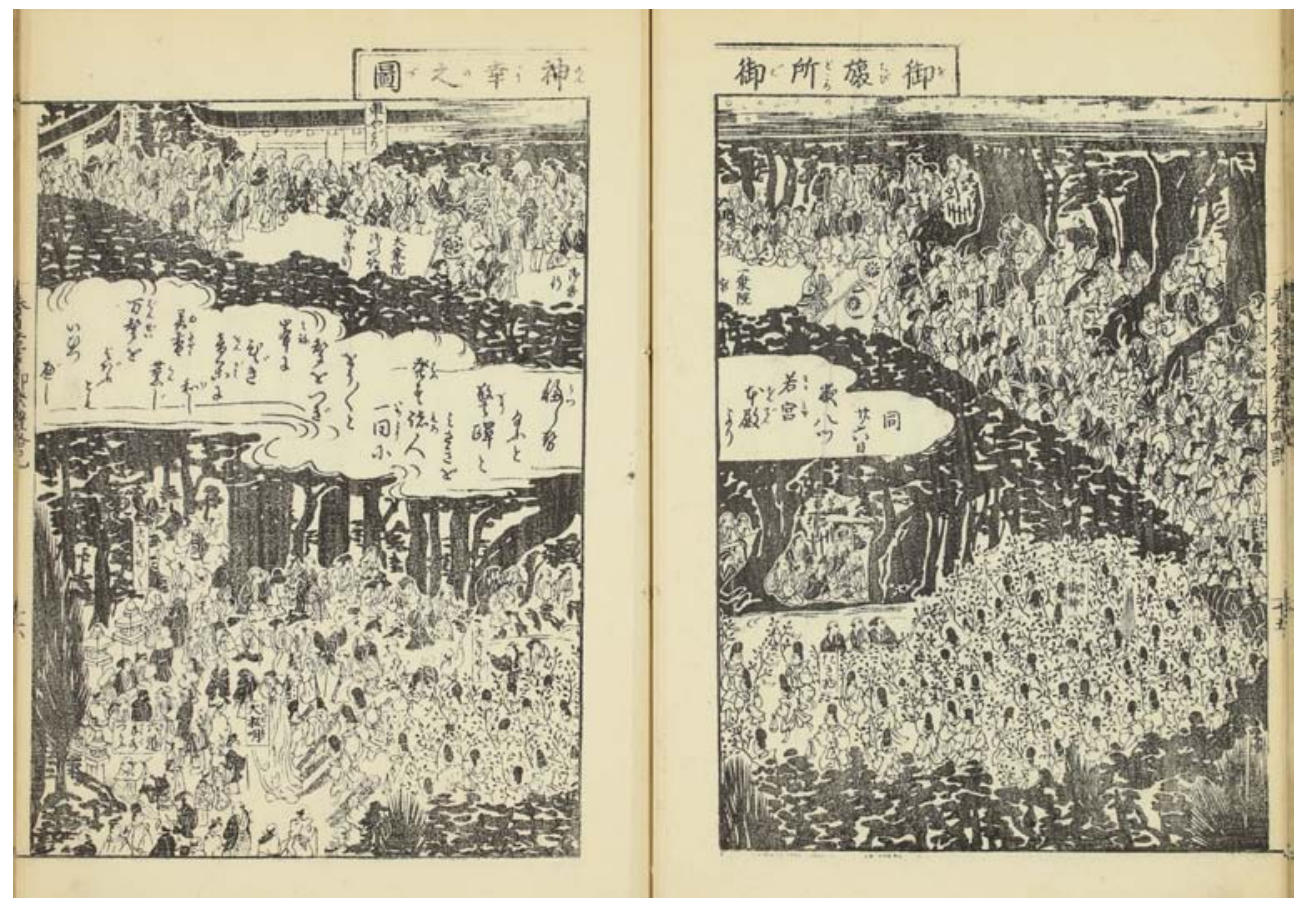

FIGURE 8.4 A moment of the Senkō no Gi procession as depicted in the Edo-period Kasuga Ōmiya Wakamiya gosairei no zu (Nagashima 1985a: 354-355). On the bottom-left corner, priests carrying huge pine torches are visible, while on the top-right side is a depiction of the musicians playing gagaku instruments, including a suspended drum.

AVAILABLE AT: HTTP://ARCHIVE.WUL.WASEDA.AC.JP/KOSHO/HA03/HA03 _00953/HA03_00953_0003/HA03_00953_0003_P0017.JPG

1680) all demonstrate that by the end of the seventeenth century, the reinvention of Onmatsuri's past was commonly accepted as historical truth (Hatakama and Yasuda 2016: 91). Nowhere is this new ideological setup more clearly illustrated than in the Kasuga Ōmiya Wakamiya gosairei no $z u$ 春日大宮若宮御祭 礼図, a collation of previously published materials compiled in 1742 (Hatakama and Yasuda 2016: 86-141; see also Hatakama 2014: 324-355) (see Fig. 8.5). ${ }^{18}$ Earlier textual evidence, however, tells a different story.

The first available sources on the matsuri are short entries in the Chüyūki 中右記, a chronicle of life at court written by Fujiwara no Munetada 藤原

18 A typographic reprint is contained in Nagashima (1985a). On the controversial identity of its author, see Hatakama (2014: $325^{-329)}$. 

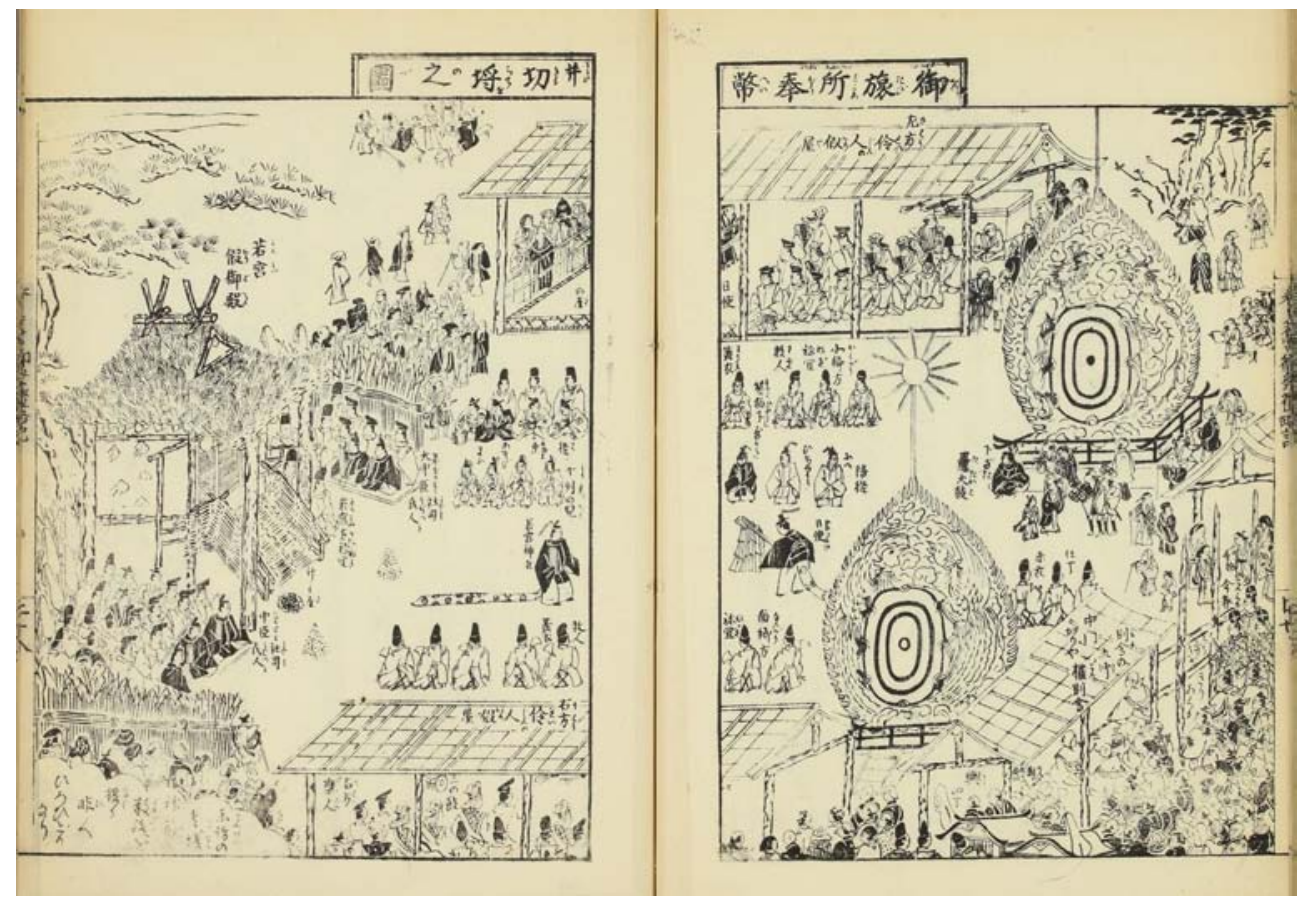

FIGURE 8.5 The area of the otabisho or temporary shrine. Two huge gagaku drums with symbols of the sun and moon frame the performance area. On the left side of the picture, the temporary shrine is clearly visible, enclosed by fences on both sides. KASUGA ÖMIYA WAKAMIYA GOSAIREI NO ZU (NAGASHIMA 1985A: 378-379). AVAILABLE AT: HTTP://ARCHIVE.WUL.WASEDA.AC.JP/KOSHO/HA03/HA03 _00953/HA03_00953_0003/HA03_00953_0003_P0029.JPG

宗忠 (1062-1141), and the Wakamiya saireiki 若宮祭禮記, a text written by Nakatomi Sukeomi 中臣祐臣 (1275-1342), a priest active at the recently established Wakamiya Shrine (Hatakama and Yasuda 2016: 4) $\cdot{ }^{19}$ Both sources state explicitly that Tadamichi set the date in which the festival should be celebrated. However, the shrine diary also states that the Onmatsuri was "an affair of the taishu [大衆]" (Hatakama and Yasuda 2016: 7). ${ }^{20}$ At the time, the terms taishu and shuto 衆徒 indicated the personnel employed at Kōfukuji (Hatakama and Yasuda 2016: 7), while the terms jinin 神人 or jinmin 神民 identified members of the Kasuga Shrine (Grapard 1992: 76, 98-99; Hashimoto 1986: 36-37). Thus, even though they do not rule out Tadamichi's role completely, primary sources

19 On the creation of the Wakamiya Shrine, see Royall Tyler (1990: $57-58$ ).

20 The original passage states: 爲大衆沙汰、若宮御祭礼始給事 (Nagashima 1985b: 439). 
seem to indicate that the birth of the festival was intimately connected to the Buddhist component of the Kasuga-Kōfukuji multiplex.

Given the frequent struggles over taxation and territorial borders between the multiplex, the Fujiwara, and the court, Hatakama Kazuhiro and Yasuda Tsuguo have suggested that the creation of the new matsuri could be understood as a public display of wealth, strength, and symbolic capital. ${ }^{21}$ If that was indeed the case, the authors suggest, the Onmatsuri might have originated from an argument between Köfukuji and the Fujiwara or the court, either as a way to request divine assistance in the matter, or, post factum, to give thanks to the kami for winning the argument (see Hatakama and Yasuda 2016: 7-19). ${ }^{22}$ Further proof for such a claim can be found in an entry in the Daijoin jisha zojjiki 大乗院寺社雑事記, a diary compiled by Jinson 尋尊 (1430-1508), the abbot of

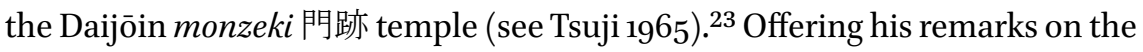
first occurrence of the Wakamiya festival, Jinson mentions that prayers were offered in connection to a "big complaint" (daiso 大訴) (Hatakama and Yasuda 2016: 10; Yasuda 2001: 16-21).

If the contribution of Kofukuji monks to the establishment of Onmatsuri seems indisputable, why did the "Tadamichi theory" eventually prevail? The answer has much to do with the delicate political balance between Kasuga and Kōfukuji. In fact, with the gradual decline of Köfukuji during the sixteenth and seventeenth century, an alternative account of the matsuri's origins became increasingly appealing to Kasuga Shrine (see Hatakama and Yasuda 2016: 7576). Eventually, due to Kōfukuji's political demise, even official Buddhist documents such as the Köfukuji yurai sono taki 興福寺由来其他記 (1727) started to accept the notion that the matsuri had been initiated by Tadamichi as historical truth-a clear testimony of the transformed socio-political landscape (Hatakama and Yasuda 2016: 94).

The so-called separation edicts (shinbutsu bunrire $i$ 神仏分離令) of 1868 further reinforced the gradual construction of a linear Shintō narrative that would

21 While both Kōfukuji and Kasuga originated as manifestations of the power of the Fujiwara family—-the former as their ujidera 氏寺 and the latter as the cultic site of worship of their ujigami 氏神—by the twelfth century the decline of the so-called sekkan seiji 摂関政治 system and the consequent shift of power from provincial governors (kokushi 国司) to more centralized authorities had set in motion a bifurcation of their political interests (see Grapard 1992: 138-139; Hatakama and Yasuda 2016: 14).

22 Indeed, the very establishment of the Wakamiya Shrine has been interpreted as an attempt to "strengthen [Kōfukuji's] hold on the Kasuga shrine" (Nagashima 1959: 9, quoted in Tyler 199o: 58; see also Ishii 1987: 35).

23 On the organization of Kōfukuji's monzeki 門跡, the temples administered by members of aristocratic families, and specifically on Jinson's diary, see Grapard (1992: 106-114, 171-185). 
eventually result in the intimate association of Onmatsuri with Kasuga Taisha. Accordingly, the policy of forcible separation of Buddhism and Shintō resulted in the abolition of Buddhist elements in the matsuri's celebrations. One particularly significant instance was the elimination of the Yabusame sadame 流 鏑馬定 and the Nandaimon gyōmyō no gi 南大門行命儀, two rites traditionally overseen by the "five masters for special ceremonies" (bechie goshi 別会 五師), important monks affiliated with Kōfukuji (see Tab. 1) (Terauchi 2011: 69). ${ }^{24}$ Together, they used to signal that the matsuri was in the hands of powerful monks belonging to Kōfukuji. Their excision thus "purified" Onmatsuri's history, facilitating the establishment of a fully Shintō narrative. Despite the reinstatement of both rites after 1985 (see Yamato Geinō Konwakai 2015: 6), linear narratives concerning the matsuri's origins have remained largely unaltered. Indeed, the revival of rituals suggesting the influence of Buddhist institutions has not affected the post-Meiji portrayal of Onmatsuri as a "Shintō event," despite the existence of textual evidence casting doubts over this interpretation.

While this reinvention of the past has provided a coherent "origin story," with Fujiwara no Tadamichi in the role of main protagonist, the modern interpretation has also rendered opaque those elements of the matsuri that would have revealed its original connections to Köfukuji. This tension between the festival's "origin story" and its "historical origins" is one of the main reasons for Onmatsuri's contemporary fractal nestedness: quite literally, different histories are folded within its ritual procedures. As the next section will demonstrate, this is not confined to Onmatsuri's history, but also extends to the multifarious representations of its kami and bodhisattvas.

\subsection{Otabishosai Fieldnotes, 17 December 2015}

Rakuson 落蹲 is a paired dance characterized by the use of yellow costumes and fearsome dragon masks with movable jaws. There is a general consensus among the musicians of Nanto Gakuso that this piece is at once the most enthralling and the most physically demanding of the whole Otabishosai. During a break on the night of 17 December 2015, T-san, a freshman at a local university and a

24 During the Yabusame sadame, the boys who would act as chigo were selected by the bechie goshi, whereas at the Nandaimon gyōmyō no gi Kōfukuji monks ostentatiously presided over the parade, announcing the name of each section passing through the Southern Gate (nandaimon). 
skilled second-generation performer of gagaku flutes, shares with me some of his views on the piece: "The melody is short, but the piece as a whole is very long, so you must go on and on repeating the same phrases. In itself, that's quite boring, but it makes it easier to get a glimpse of the dancers onstage. You play pretty much automatically, especially because by the end of the day you're really tired. Still, I think that state you're in is probably the best way to appreciate Rakuson. I remember studying the dance movements: it's tiring, because you keep going down on your knees and getting up. But [during the actual performance] the atmosphere is mysterious (fun'iki wa shinpiteki 雾囲気は神秘 的), especially because it comes at the end of a long matsuri."

After the break, we go back to the gakuya 楽屋, the musicians' room, and we play until the end of the ritual, two hours later. Glimpsing the stage during Rakuson, I can't help but notice that the dancers almost never face the audience: for the most part, their torsos point toward the temporary shrine. Every time they crouch or lower their heads, the movements make me think of a deep, ceremonial bow. In this way, Rakuson communicates a sense of distance from the human world: as the last performance of the daylong Otabishosai, it constitutes at once a sonic and physical invocation, giving tangible form to the ethereal domain of the kami.

\subsection{Parts Becoming Wholes}

Whether we choose to interpret it as a timeless Shintō ritual, a modern concoction, or a commodified example of heritage preservation, for over seven centuries Onmatsuri has been the favorite meeting place of the people of Yamato and their deities. Of course, this is true of many matsuri, for "Japanese gods exist and thrive mainly through ritual. It is ritual that literally brings them down to earth, in the life of the worshiper, or more precisely in the purified arena prepared for them" (Faure 2016: 40). But how does Onmatsuri exemplify and, for some participants, convey the theophany of its specific deity? What are the features of Onmatsuri's object(s) of worship, and how do these features translate into a specific symbolism? Trying to answer these questions, this section shows that the "gods of Nara" are complex composite figures: assemblages with shifting, fractal identities, they not only fit into, but also help generate Onmatsuri's nested structures.

As indicated by its name, the Kasuga Wakamiya Onmatsuri revolves around the kami enshrined in the Wakamiya Jinja. The identity of this deity can be traced back to the interrelation of the four kami venerated at the Kasuga Grand Shrine. Ame no koyane no Mikoto 天児屋根命 (in the Third Sanctuary) and his consort Himegami 比売神 (Fourth Sanctuary) were probably the first deities to be installed there during the seventh or early eighth century; they are "agrar- 
ian gods from old Kawachi province [河内国] (to the east of modern Osaka), where the Fujiwara originated" (ten Grotenhuis 1999: 145). By the middle of the eighth century, two war gods were added to the cult:Futsunushi no Mikoto 経津 主命 (Second Sanctuary) and Takemikazuchi no Mikoto 武鹳桘命 (First Sanctuary). ${ }^{25}$ As for the kami known as Wakamiya, the earliest testimony is a document of the Chidori 千鳥 family, the branch of the Nakatomi 中臣 in charge of the shrine since its foundation in 1135 (see Royall Tyler 1990: 62; Grapard 1992: 101). According to this record, "in the third month of 1003, a translucent, gelatinous mass formed on the underside of the floor of the Fourth Sanctuary [of the Kasuga Shrine]. The mass soon grew so large and heavy that it fell, and from it emerged a little snake. The snake crawled up the northwest pillar of the structure and disappeared into the sanctuary" (quoted in Tyler 1990: 57; see also Ōhigashi 1982: 8). ${ }^{26}$ Immediately, it was clear that the snake was the child of the divine couple Ame no Koyane and Himegami. As such, it was moved to an independent building in 1135, thus establishing the Wakamiya Shrine. ${ }^{27}$ Concurrently, the kami was given the name Ame no Oshikumone no Mikoto 天押雲根命.

Inseparable from this process of identification was the larger context of medieval honji suijaku 本地垂跡, "the idea that local, native deities (kami) are emanations of universal, Buddhist divinities" (Teeuwen and Rambelli 2003: 1). ${ }^{28}$ Accordingly, Ame no Oshikumone could be represented either as the bodhisattva Monju 文殊 (Sk. Mañjuśrī) or as Kannon 觀音 (Sk. Avalokiteśvara) (ten Grotenhuis 1999: 147). For Grapard, "when the Wakamiya kami is represented as Monju, who is often depicted in Buddhist iconography as a youth, it is represented as a youthful entity" (Grapard 1992: 88). The connection with Kannon, on the other hand, "may be related to youth initiation or to the feminine character of young men who were the object of romantic attachments on the part of some aristocrats and monks of various temples" (Grapard 1992: 89). Indeed, given the prominent role of young boys (chigo) in medieval rituals at Kōfukuji, including Onmatsuri's Yabusame sadame, such erotic overtones seem

25 Allan Grapard has traced the origins of each deity, showing the significance of their cult for the Nakatomi-Fujiwara clan (Grapard 1992: 29-44).

26 For the original text, see Naraken Kyōikukai (1987).

27 The term "Wakamiya" is used generically to identify cultic sites whose enshrined deities are the offspring of kami venerated at a "main shrine" (Kokugakuin Daigaku Nihon Bunka Kenkyūjo 1994: 44-45).

28 At Kasuga, the pairing of kami and buddhas "reflected the intimate association between Kasuga and Kōfukuji, which ranged from religious practice to administrative and financial organization" (ten Grotenhuis 1999: 146-147). For a useful chart of the main associations between Kasuga kami and Kōfukuji buddhas and bodhisattvas from the late Heian to the Sengoku period, see ten Grotenhuis (1999). 
plausible (see also Terauchi 2011: 70). According to Bernard Faure, on the other hand, "at the Wakamiya Shrine of Kasuga, Daikokuten [大黒天] (or rather Ōkuninushi [大国主]) is worshiped today as part of a couple, together with Okame お亀 (a.k.a. Otafuku お多福, the popular version of the goddess Ame no Uzume 天宇受売)" (Faure 2016:53-54). As these contrasting hypotheses reveal, the question of the identity of the Wakamiya deity cannot be resolved through recourse to either Shintō divine genealogies or Buddhist depictions in isolation: instead, a more complex articulation of signifiers is at play in medieval Japanese religious practices.

This productive "assemblage" of kami and Buddhist deities was not confined to external signifiers: each deity was "a combination of a plurality of divine entities" and "a multifaceted entity with many names and many appearances" (Teeuwen and Rambelli 2003: 2, 30 emphasis added). In fact, "originals and traces were not one-to-one associations, but complex combinations of several deities based on sophisticated semiotic operations, myths, legend, and so on" (Teeuwen and Rambelli 2003: 1-2). For Faure, Japanese medieval gods were "networks" or "hybrids" (Faure 2016: 26, 38) whose "essential multiplicity can never be reduced to an essence or contained in a taxonomy" (Faure 2016: 43 emphasis added). Medieval deities such as the ones enshrined in the KōfukujiKasuga multiplex could be "assembled" (Teeuwen and Rambelli 2003: 30), but their phenomenological presence did not rest on clear-cut manifestations of completeness (see Faure 2016: 44).

In this eminently "fluid pantheon," in which "the play of analogies and identities allows the emergence of new lateral, rhizome-like relations between the gods" (Faure 2016: 31), the entities venerated in Nara gradually converged toward the unitary-but-multiple figure of Kasuga Daimyōjin, "the numinous unit of the associated kami and buddhas/bodhisattvas of the Kasuga-Kōfukuji multiplex" (Grapard 1992: 93) ${ }^{29}$ Literary and artistic works such as the Kasuga Gongen genki provide a stark depiction of the process: in the medieval scroll, the entity appears in different guises, including a deer, a lady, a young boy, a sakaki tree, and so on. ${ }^{30}$ Similarly, diverse representations of Kasuga Daimyō-

29 Grapard notices that "the term Kasuga myöjin appears for the first time in a document written by a monk of the Enryakuji on Mount Hiei in 859" and that "by the 12th century Kasuga daimyōjin formed a single entity as protector of land in various provinces, and it was becoming the protector of the entire province of Yamato" (Grapard 1992: 93, 95).

Myōjin and gongen are highly ambiguous terms, belonging to a "moot category" of Japanese divine beings (Teeuwen and Rambelli 2003: 29). While myōjin refers to "a single divinity, several divinities, or a unified group of divinities" (Grapard 1992: 93), gongen could be translated as "provisional manifestation" (Faure 2016:27), and indicated "neither native kami nor divinities from the Buddhist pantheon; rather, they were virtuous beings 
jin and its terrestrial abode gave rise to popular artistic genres, including both “deer mandalas" (shika mandara 鹿曼茶羅) and aerial representations of Nara's cultic centers, interpreted as a sacred realm or a special pure land on earth. ${ }^{31}$ The influence of such imagery on Japanese medieval culture at large is attested by the dissemination of poems and Nō plays citing or alluding to Kasuga Daimyōjin (such as Kasuga Ryūjin 春日龍神), the sacred Mikasayama hill on which the Kasuga Shrine rests, or the sacred landscape of Nara as a whole (see Royall Tyler 1990: 127-144).

In this context, localized manifestations of the fluid constellation of signs and practices associated with Nara and its deities were likely to be perceived metonymically: the kami of Wakamiya and its festival, for instance, could stand for "the symbolic body of the province of Yamato" (Grapard 1992: 162). When these metonymic associations were mobilized successfully, social cohesion was at once strengthened and publicly represented (see Hashimoto 1986: 61). Thus, the Onmatsuri was not just a collective celebration, or merely the product of political struggles among the multiplex, the Fujiwara, and the court: it was also the moment in which a "macrosemiotic entity" (Teeuwen and Rambelli 2003: 48) was given the form of a real-life event, a phenomenologically rich experience that engaged the community through the five senses as much or even more than through the powers of symbolic representation.

The metonymic character of some of the most important religious signifiers circulating in medieval Nara is apparent in a number of elements that are central to the "Onmatsuri atmosphere": from purportedly "minor" ritual events to architectonic and artistic hidden references, the specific identity of the kami or the form it assumed was perhaps less important than the activation of physical and intellectual states - the feelings of something manifesting itself. ${ }^{32}$ After all, "the name of a god does not designate a gathering or subsum-

from foreign lands who travelled to Japan to bring benefits to its people, and, in particular, to promote the cause of Buddhism" (Teeuwen and Rambelli 2003: 29).

31 On deer mandalas, see especially ten Grotenhuis (1999: 157-159); Susan C. Tyler (1992: 6773). On shrine mandalas and the Gongen emaki, see also Susan C. Tyler (1992: 115-183); Hardacre (2017: 185-193).

32 Fabio Rambelli similarly notes that "sutras today (and perhaps, to a certain extent, also in the past) ... tend to function as just another liturgical implement, as part of the ritual setting. As such, they contribute to create a Buddhist 'atmosphere,' much like design artifacts and commodities" (Rambelli 2007: 104). He further links the atmospheric role of liturgical implements to "the cultural trend to express one's feelings and emotions through fashionable commodities," suggesting that the connection between atmospheres and material artifacts can be traced back to Tanaka Yasuo's novel Nantonaku, kurisutaruなんとなく、 クリスタル (Rambelli 2007: 270). For a discussion of the novel, see Field (1989). 
ing (of the multiple into unity), but a metaphoric deployment, a permanent onto/morpho-genesis" (Faure 2016: 38). Thus, a medieval matsuri could be conceived as that moment in which an instance of "onto/morpho-genesis" is made tangible: imbued with symbols, words, and the potential to become "particular occurrences of the different modes of existence and manifestation of a sacred entity" (Teeuwen and Rambelli 2003:53), buddhas and kami are parts becoming wholes. Matsuri, in this sense, can be understood as fractal entities that contain within themselves entire networks of divine associations.

In the next section, I will focus on two examples of how Onmatsuri's "divine assemblages" contribute to the emergence of specific "atmospheres of the past," closing in on yet another scale of the festival's self-similarity: ritual participation.

\section{5 Of Masks, Dragons Scales, and the Atmospheres of the Past}

Since ancient times, the Wakamiya deity has been associated with water and water sources. In the Kojiki 古事記 (712), for example, Ame no Oshikumone is described as "the kami charged with fetching 'Heavenly Water' from the wells atop Mount Futagami [二上山] for the enthronement ceremony of emperors," and is thus "symbolized by a snake or dragon" (Grapard 1992: 88). The symbolism might even date back to local kami cults. According to Hashimoto Hiroyuki, for instance, the snake appearing in the Chidori document alludes to a "primordial Kasuga faith" (gen Kasuga shinkō 源春日信仰), ancient beliefs that grew in and around Mount Mikasa long before the Kōfukuji-Kasuga multiplex came into existence (Hashimoto 1986: 13-15, 25). Hashimoto links these ancient cults to rainmaking rituals, ascetic practices, and dragon cults-practices through which "society acknowledges the 'other world' through boundaries" (Hashimoto 1986: 17). For him, watercourses are physical metaphors for the boundaries of the social body: the emergence of the Wakamiya deity is thus a logical evolution of earlier forms of kami worship rooted in the symbolism of water.

Furthermore, the creation of a new shrine connected to a supernatural snake also aligned with broader shifts in medieval Japanese society regarding the association of religious practices with the semantic field of water. As David Bialock notes,

by the late Heian and early medieval period, the sacrality of water deities (mizu no kami 水の神) in their various guises as serpent (orochi 大蛇), snake (hebi 蛇), dragon king (ryūō 龍王), dragon girl (ryūnyo 龍女) and 
the like, underwent a fresh reinvestment of meaning as a variety of factors converged to transform them into a richly ambiguous symbolic site for mediating many of the contradictions in medieval culture.

BIALOCK 2OO2: 281

The presence of a salamander pond in the vicinity of the Wakamiya Shrine thus suggests the appropriateness of the site for the creation of a festival which, although probably initiated by Kōfukuji monks, was integrated in the cosmological world of the kami venerated at Kasuga (cf. Grapard 1992: 16o). In this regard, the overlap of Buddhist and Shintō elements characterizing the origins of the Onmatsuri is typical of "medieval Shintō" as a whole. As noted by Andreeva, in fact, "in medieval Japan, serpent symbolism became ingrained in the iconography, doctrinal elucidations, and rituals of a whole cluster of religious and performative practices built on the Buddhist worldview and focused on kami" (Andreeva 2017:307). When it comes to Onmatsuri's present form, however, the sacrality of water deities is not an echo of the distant past but a rich semiotic motif especially discernible in the rites of the Otabishosai.

Architectural details, for instance, might bear witness to the continuity of cosmological themes. During the construction of the temporary shrine, triangular blocks of white paper are inserted into the outer walls of the karino miya building. These rustic decorations remain clearly visible when the mud walls solidify (see Fig. 8.3), but their meaning is far from transparent:

it has been suggested that the blocks might contain words inscribed on a sheet of paper set in their middle, but there is no indication of what these words might be. Potent utterances (dhäranī)? Japanese poems? Names of divinities? Requests? Divinatory formulas? It has also been suggested that the triangular blocks represent dragon scales.

GRAPARD 1992: 159-16o (emphasis added)

Because the earth used to build the walls was collected from areas inhabited by onmyōji 陰陽師, scholars also suggested that the white triangular "scales" may bear some connections with ancient yin-yang practices (Yamamichi 1991: 162).

When questioned about this peculiar architectural feature during the ritual on 17 December 2018, M-san, a Kasuga priest and member of Nanto Gakuso, dismissed overly complicated interpretations, insisting that the triangles should be seen as "decorative and artistic." Pushed for further comments, he concluded that "even if the majority of the people don't know what these things stand 
for, they are still an element of the matsuri, and can make people more curious." While the symbolic and likely esoteric relevance of these blocks remains unclear, their presence attests to the fact that specific layers of meaning have been physically inscribed in the ceremony. M-san's remarks also indicate an awareness of the role of metonymic and fractal signs related to water (deities) in the establishment of a particular ritual atmosphere. Similarly, the bugaku dances performed at the end of the Otabishosai contain allusive reminders of the snake/dragon/water deity of Wakamiya.

In contrast with the first "auspicious" dances, the last bugaku pieces performed by Nanto Gakuso-Ran'ryōo 蘭陵王, Nasori 納曽利 and Rakuson 落 躑—are lively and assertive, characterized by the use of vivid masks and distinctive costumes (see Tab. 1). While Ran'ryōo is associated with the story of a Chinese king of such beauty that he was forced to put on a fearful dragon mask in order to encourage his troops to fight, Nasori and its twin dance Rakuson are known as the "dances of the two dragons" (sōryū no mai 双竜舞) (Lee 1965: 235) (Fig. 8.6)..$^{33}$ The Otabishosai ends with a performance of Rakuson, a modified version of Nasori with two masked dancers instead of one. ${ }^{34}$ The piece is characterized by a "crouching" movement, perhaps alluded to in the second character of the title, uzukumaru 䄞, which has exactly that meaning. Hashimoto takes this movement to mean both "gathering energy" and "waiting for the next year" (Hashimoto 1986: 106-109). For him, Rakuson stands as a symbol of the "cosmic cycle of renewal," and the dancers' bodies represent the "externalization of the other-that-lives-in-us" (Hashimoto 1986: 107). More plainly, we could say that the link between the piece and dragons/snakes is coherent with the mythical origins of the Wakamiya deity: such presences are consistent with the symbolic economy of meanings at play during the Onmatsuri. The fact that an allusion to a serpent-like figure should come from the performers is far from coincidental, given that "in the medieval period, water deities in the form of dragons assumed great importance as the tutelary divinity of travelers, traders, and those engaged in entertainment, especially musicians" (Bialock 2002: 281).

Such traces of early cults do not amount to signs of universal human structures, as Hashimoto suggests; nor are they manifestations of what Grapard calls

33 For more detailed information on the origins and musical characteristics of the pieces, see Endō (2013: 341-342).

34 This performance style is unique to Nara gagaku. Other groups perform Nasori as a twoperson dance, and Rakuson with only one dancer on stage (Endō 2013: 342; Terauchi 2011: $83)$. 


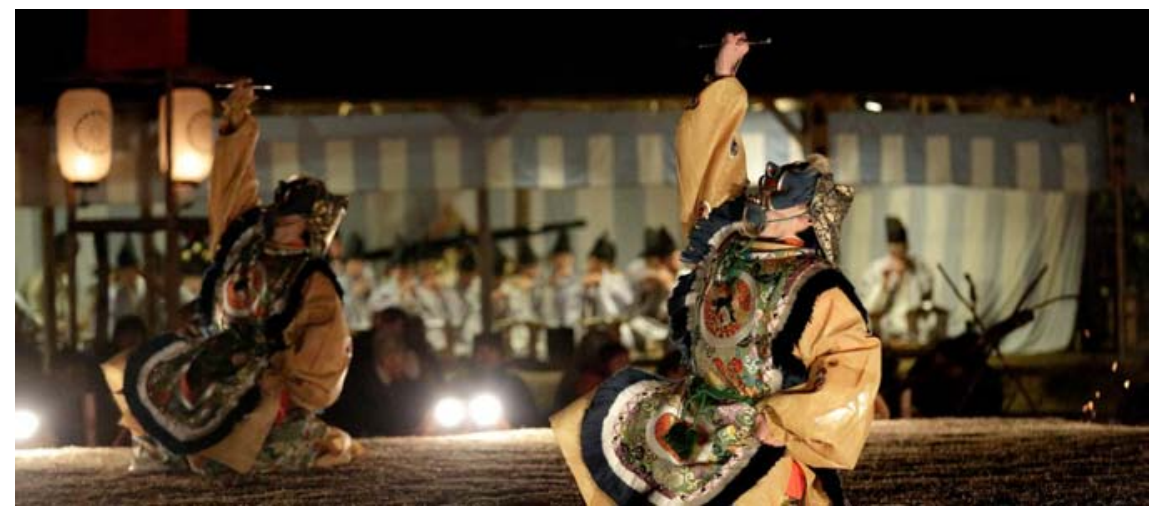

FIGURE 8.6 Final moments of the dance Rakuson. The crouching posture and upward movement of the hand are hallmarks of this pair dance and have been interpreted as gathering energy from the sky and transferring it to this world. SEE HASHIMOTO 1986: 106-109. HTTP://WWW.КOTO-NETPRESS.COM/ BOOKMARK/ONMATSURI/SIGHT/SCENE03.HTML (C) 2015 KANSAICREATIVE.INC. ONMATSURI HOZONKAI

the "logic" of the Onmatsuri, according to which "the symbolic body of the province (the kami) and the hierarchical social body of men must merge in a single identity" (Grapard 1992: 165). Rather, they act as localized manifestations of the fractal nature of the deity celebrated every winter, and re-present it each time the festival takes place. Ultimately, the function of scales, dragon masks and crouching movements is neither exclusively vestigial nor exclusively symbolic: it is at once both and more than the sum of these aspects. As I show in the remainder of the paper, in fact, these material-semiotic elements are central to the activation of a process of sensory attunement that generates and is generated by an "atmosphere of the past."

With the expression "atmosphere of the past," I refer to the felt evocation of complex systems of feelings enabled by "ostensive signs" such as the costumes in a parade, the music performed, or the ritual symbols displayed. ${ }^{35}$ Although "evocations of the past" is a valuable alternative, recently the term "atmosphere" has gained currency in the context of anthropological and ethnomusicological research. ${ }^{36}$ Indeed, music and atmosphere are often under-

35 "Ostension" was defined by Umberto Eco as a semiotic phenomenon occurring "when a given object or event produced by nature or human action ... is 'picked up' by someone and shown as the expression of the class of which it is a member" (quoted in Rambelli 2013: 12). On the theme of ostension in Buddhist semiotics, see Rambelli (2013: 1113).

36 Recent studies of atmospheres, music, and sound include Abe (2014, 2018); Eisenlohr 
stood as coterminous phenomena: "it seems that wherever music resounds, feelings are likely to unfold as perhaps vague, but nonetheless intrusive and pervasive, spatially extended atmospheres" (Riedel 2019: 2). Grounded in the contemporary "radical empiricism" of affect theory and "process philosophy," the concept of atmosphere is mobilized by anthropologists and ethnomusicologists with specific reference to "a shared sense of affective intensity ... occupying an immersive, resonant, and spherical spatiality, much like sound itself" (McGraw 2016: 131). ${ }^{37}$ Not to be construed as a mere synonym for the felt environment, "the atmospheric" captures a quasi-meteorological dimension of states-of-being in formation: "an atmosphere is not an inert context but a force field in which people find themselves. It is not an effect of other forces but a lived affect - a capacity to affect and to be affected that pushes a present into a composition, an expressivity, the sense of potentiality and event" (Stewart 2011: 452; see also Anderson 2009). ${ }^{38}$

In research on sound or music, atmospheres are predominantly addressed as "states" that characterize a specific milieu and the collective inhabiting it, rather than particular individuals. Indeed,

"atmosphere" or an "atmospheric situation" describes a "feeling" that fundamentally exceeds an individual body or conscious subject, and instead pertains primarily to the overall situation in which a multiplicity of bodies cohere. Atmosphere thus challenges a notion of feelings as being private or even as being the mere mental states of a cognizant subject, and instead construes feelings as spatially extended, environmental, collective, materially tangible, culturally inflected or "asubjective."

RIEDEL 2O19: 4

The notion of atmosphere also helps to detect "forms of sociality [otherwise] difficult to observe" (McGraw 2016: 140), and thus can be productively applied to the anthropological study of rituals. This kind of "atmospheric sociality" (McGraw 2016: 140) is emergent and diffuse: less normative than Durkheim's "collective effervescence," it can be used to describe fleeting but sensorially rich experiences of the kind described by my interlocutors. Acting as "acoustic philosophers" (Abe 2018), the musicians of Nanto Gakuso acknowledge the contribution of gagaku and bugaku to the emergence of Onmatsuri's charac-

(2018); McGraw (2016); Plourde (2014, 2017, 2019); Riedel (2019); Riedel and Torvinen (2019); Roquet (2016).

37 For a variety of approaches to affect, see Wetherell (2012); White (2017).

38 For a different use of the term, specific to Japanese media, see Roquet (2016). 
teristic atmosphere. In doing so, they link their artistic practices to metonymic, fractal or otherwise "ostensive" signs. These signs, in turn, point towards the past not just as an interpretive category, but as a rich repository of associations that can be activated through ritual participation. That participants point toward the atmospheric dimension of the music they play in relation to the past is hardly surprising; echoing Friedlind Riedel, we could say that for the members of Nanto Gakuso "atmosphere manifests as a relation to the past" (Riedel 2019: 32).

As an intangible but indispensable dimension of the festival, atmospheres of the past affect the quality of matsuri participation, shaping its environmental affordances. From an internal perspective, in fact, "the labored viscerality of being in whatever's happening renders choices and surfaces already weighty with the atmosphere one is literally attuning to" (Stewart 2011: 451). ${ }^{39}$ Thus, it is primarily the affective potential of atmospheres that makes the concept so valuable: because they are actively partaking in something "out of the ordinary," spectators and actors alike become aware that their own ritualized presence is "an aspect of their experience" (Schieffelin 2006: 621). In other words, "the process or activity itself becomes their mode of mutual sociality" (Schieffelin 2006: $624)$. From this point of view, a ritual is also the sociality that it produces-and sociality, though undoubtedly heterogeneous, is largely an effect of felt relations, or atmospheres. In their affective capacity, atmospheres are not merely constructed, but also generative. ${ }^{40}$

The circulation of interconnected symbols that reinforce a perception of coherent part-whole relations gives form to this affective-semiotic process of participation. In the case of Onmatsuri, in fact, particular "sensory surfaces" are inscribed with fractal objects, such as the architectonic "dragon scales," the masks, the movements of the dancers, and the sounds of gagaku. These symbols recall and contribute to the emergence of the overall phenomenological experience of the matsuri: as noted by Brian Massumi, in fact, "some atmospheres can enable a 'felt-reality of relation'” (quoted in McGraw 2016: 142). Similarly, processes of attunement to the past are often the subject of my dis-

39 At the same time, and not in contradiction to this dynamic, ritual participation may also be described by participants in passive terms: as "a particular state of consciousness or experience characteristic of a group under conditions of emotional arousal and collective effervescence while engaged in ritual activity, [participation] is characterized by the group members' sense of 'abandoning themselves to' or 'being submerged in' or 'overcome by' a kind of external force, a larger compelling process, group identification, or superior (sacred) presence" (Schieffelin 2006: 615).

40 From this point of view, as recently observed by Riedel (2019: 89), "creating and mobilizing atmospheres can be considered a technology of power." 
cussions with Nanto Gakuso members. This is so because, to a greater extent than is generally recognized, "ritual efficacy" is also about the intimacy of sharing an atmosphere: the feeling of being part of an event (the whole) contained in the space of a single moment (a part of that whole) (see Sørensen 2006).

Evocations of this kind are not restricted to human interactions. Rather, they extend to participants' relations with supernatural entities. Deities are more than the signs and semiotic processes at play in a ritual event: they, too, can dwell in "the vanishing trace of a presence, perhaps a floating feeling of uncanniness, fear, or joy, caused by a close encounter with an elusive higher power. Discourse about gods reveals not merely the content of beliefs but a certain existential or phenomenological tonality, which is always at risk of slipping through the meshes of symbolic discourse" (Faure 2016: 48 emphasis added). This phenomenological tonality is powerfully brought to the fore by ethnographic encounters, especially when, as in my own experience with Nanto Gakuso, ritual participation is shared through performance.

Performing Rakuson, one cannot but sense that music and dance are offered to humans and nonhumans alike: music and dance feed into the atmosphere of the festival because they are appropriate elements of that atmosphere. Of course, these phenomenological overtones are not open to all: ritual participation presents itself at once as spontaneous and rigidly governed. But for my interlocutors, this is far from paradoxical, because the kind of coherence they experience need not be linear. Onmatsuri's entirety is folded in the individual pages of its celebrations. Its fractal logic makes one feel the pliancy of the partwhole relations every time a symbol is evoked or encountered. In this way, the matsuri rests upon affective and atmospheric encounters with the past, disclosing, generating, and remolding the felt presence of innumerable "partial connections" (Strathern 2004).

In this chapter, I have revisited both the history and the contemporary structure of Nara's most important religious festival, the Kasuga Wakamiya Onmatsuri. Combining ethnographic materials and historical sources that shed light on its religious background, I have argued that accounts that follow a "linear narrative" tend to ignore the matsuri's composite features, downplaying the role of Buddhist institutions in the festival's creation. Through my analysis, I have also tried to deconstruct simplistic accounts that tend to portray the matsuri as an unchanged iteration of the same events throughout the centuries. To counter this supposedly unproblematic narrative, I have tack- 
led the complexity of the matsuri by highlighting its heterogeneous features. Approached in this way, Onmatsuri emerges as a "composite of composites" (see Mol 2016).

I have paid particular attention to two aspects of the festival's complexity: its "fractal" characteristics, and the circulation of "atmospheres of the past" through material and semiotic symbolism. I have demonstrated that the history of the festival is folded in its constitutive events in such a way that access to its parts reinforces a sense of participation in a coherent whole. At the same time, I have tried to show that ritual participation functions experientially by virtue of specific signs inscribed with evocative meanings. Examples include the triangular blocks inserted in the walls of the temporary shrine and the dances performed during the Otabishosai ritual. These elements confer a distinctive "phenomenological tonality" to ritual participation. It is thanks to the tension between its fractal entanglements and "atmospheric attunements" (Stewart 2011) that Onmatsuri has managed to retain its significance in the spiritual ecology of Nara province.

Future research on Onmatsuri will elucidate other ways in which the festival's complexity has manifested itself in modern times, such as the role of transportation networks in the transformation of the matsuri into a popular tourist attraction; ${ }^{41}$ the ways in which local stakeholders transformed Onmatsuri from a provincial festival into "the festival of Nara city" (Nara no shimatsuri 奈良の市祭) (Hatakama and Yasuda 2016:158); the processes of preservation, restoration, and renewal set forth by the nomination of the "Shintō Performing Arts of the Kasuga Shrine" as Important Intangible Folk Cultural Heritage. These lines of enquiry should be pursued via a combination of history, religious studies, and anthropology, because Onmatsuri's past is often inscribed in the lived memory of many of its current participants, including the musicians and dancers of Nanto Gakuso. Through further integrations of oral history, ethnographic research, and ritual studies, we may be able to reach a deeper understanding of how materiality, religiosity and complex semiotic processes intertwine in sensuous ways. In the context of Nara's specific "culture of place" (Grapard 1992: 258), in fact, "as place is sensed, senses are placed; as places make sense, senses make place" (Feld 1996: 91).

41 On this aspect, see Hatakama and Yasuda (2016: 150-165). 


\section{Acknowledgments}

This work was supported by JSPS Kakenhi Grant Number ${ }_{17} \mathrm{~F}_{17760}$ "Past Futures: Gagaku's Experimental Developments Within and Beyond the National Theatre" (2017-2019). Special thanks are due to the members of Nanto Gakuso and their leader, Mr. Kasagi Kan'ichi 笠置㑆一 for allowing me to take part in the Onmatsuri celebrations on three different occasions (2013, 2015, 2018). I also wish to thank Daniele Sestili and Suzuki Haruo 鈴木治夫 for precious introductions, as well as the editors of this volume, Fabio Rambelli, and an anonymous reviewer of the Journal of Religion in Japan for their insightful comments.

\section{References}

Abe, Marié. 2014. "Sounding Imaginative Empathy: Chindonya's Affective Economies on the Streets of Osaka." In Sound, Space and Sociality in Modern Japan, eds. Joseph D. Hankins and Carolyn S. Stevens, New York: Routledge, 89-107.

Abe, Marié. 2018. Resonances of Chindon-Ya:Sounding Space and Sociality in Contemporary Japan. Middletown: Wesleyan University Press.

Akagawa, Natsuko. 2015. Heritage Conservation and Japan's Cultural Diplomacy: Heritage, National Identity and National Interest. New York: Routledge.

Anderson, Ben. 2009. "Affective Atmospheres." Emotion, Space and Society 2(2): 77-81. Andreeva, Anna. 2017. Assembling Shinto: Buddhist Approaches to Kami Worship in Medieval Japan. Cambridge: Harvard University Asia Center.

Ashkenazi, Michael. 1994. "Festival Management and the Corporate Analysis of Japanese Society." In Unwrapping Japan: Society and Culture in Anthropological Perspective, eds. Eyal Ben-Ari, Brian Moeran, and James Valentine, Honolulu: University of Hawai'i Press, $152-163$.

Bialock, David T. 2002. "Outcasts, Emperorship, and Dragon Cults in The Tale of the Heike." Cahiers d'Extrême-Asie 13(1): 227-310.

Eisenlohr, Patrick. 2018. Sounding Islam: Voice, Media, and Sonic Atmospheres in an Indian Ocean World. Oakland: University of California Press.

Endō, Tōru 遠藤徹. 2013. Gagaku o shirujiten 雅楽を知る事典. Tokyo: Tōkyōdō Shuppan. Faure, Bernard. 2016a. Gods of Medieval Japan: The Fluid Pantheon. Honolulu: University of Hawai'i Press.

Faure, Bernard. 2016b. Gods of Medieval Japan: Protectors and Predators. Honolulu: University of Hawai'i Press.

Feld, Steven. 1996. "Waterfalls of Song: An Acoustemology of Place Resounding in Bosavi, Papua New Guinea." In Senses of Place, eds. Steven Feld and Keith H. Basso, Santa Fe: School of American Research Press, 91-136. 
Field, Norma. 1989. “Somehow: The Postmodern as Atmosphere.” In Postmodernism and Japan, eds. Masao Miyoshi and H.D. Harootunian, Durham and London: Duke University Press, $169-188$.

Foster, Michael Dylan. 2015. "Imagined UnE Sco s: Interpreting Intangible Cultural Heritage on a Japanese Island." Journal of Folklore Research 52(2-3): 217-232.

Gerholm, Tomas. 1988. "On Ritual: A Postmodernist View." Ethnos 53(3-4): 190-203.

Grapard, Allan G. 1992. The Protocol of the Gods: A Study of the Kasuga Cult in Japanese History. Berkeley: University of California Press.

Grimes, Ronald L. 2013. The Craft of Ritual Studies. New York: Oxford University Press. ten Grotenhuis, Elizabeth. 1999. Japanese Mandalas: Representations of Sacred Geography. Honolulu: University of Hawai'i Press.

Hardacre, Helen. 2017. Shinto: A History. New York: Oxford University Press.

Hashimoto, Hiroyuki 橋本裕之. 1986. Kasuga Wakamiya Onmatsuri to Nara no kosumorojī 春日若宮おん祭と奈良のコスモロジー. Tokyo: Tōkyō Gaikokugo Daigaku Ajia to Afurika Gengo Bunka Kenkyūjo.

Hatakama, Kazuhiro 幡鎌一弘. 2014. Jisha shiryō to kinsei shakai 寺社史料と近世社会. Kyoto: Hōzōkan.

Hatakama, Kazuhiro 幡鎌一弘 and Yasuda Tsuguo 安田次郎. 2016. Sairei de yomitoku rekishi to shakai: Kasuga Wakamiya Onmatsuri no goo nen 祭礼で読み解く歴史と社 会-春日若宮おん祭りの900年. Tokyo: Yamakawa.

Ishii, Tatsurō. 1987. "The Festival of the Kasuga Wakamiya Shrine." Theatre Research International 12(2): 134-147.

Kalland, Arne. 1995. "A Japanese Shintō Parade. Does It "Say" Anything, and If So, What?" In Ceremony and Ritual in Japan: Religious Practices in an Industrialised Society, eds. Jan van Bremen and D.P. Martinez, New York: Routledge, 161-182.

Kasuga Kogaku Hozonkai 春日古楽保存会 (ed.). 1982. Kasuga Wakamiya Onmatsuri no shinji geino 春日若宮おん祭の神事芸能. Kasuga Taisha.

Kokugakuin Daigaku Nihon Bunka Kenkyūjo 国学院大学日本文化研究所 (ed.). 1994. Shintōjiten 神道事典. Tokyo: Kōbundō.

Kunaichō Sannomaru Shōzōkan 三の丸尚蔵館 (ed.). 2018. Kasuga Gongen genki e: Yomigaetta Kamakura emaki no meihin 春日権現験記絵一更生つた鎌倉絵巻の名品. Tokyo: The Museum of the Imperial Collections, Sannomaru Shōzōkan.

Lancashire, Terence. 2013. "What's in a Word?: Classifications and Conundrums in Japanese Folk Performing Arts." Asian Music 44(1): 33-70.

Lee, Hye-ku 李恵求. 1965. “Nasorikō” 納兽利考. Tōyo ongaku kenkyū 東洋音楽研究 18: 235-242.

McGraw, Andrew. 2016. "Atmosphere as a Concept for Ethnomusicology: Comparing the Gamelatron and Gamelan." Ethnomusicology 6o(1): 125-147.

Minamitani, Miho 南谷美保. 20o8. Shitennōji Shōryōe no bugaku 四天王寺聖霊会の舞 楽. Ōsaka: Tōhō Shuppan. 
Misumi, Haruo 三隅治雄. 1982. “Onmatsuri No shinji geinō” おん祭の神事芸能. In Kasuga Wakamiya Onmatsuri no shinji geinō 春日若宮おん祭の神事芸能, eds. Kasuga Taisha 春日大社 and Kasuga Kogaku Hozonkai 春日古楽保存会, Nara: Kasuga Taisha, $66-75$.

Mol, Annemarie. 2016. "Clafoutis as a Composite: On Hanging Together Felicitously." In Modes of Knowing: Resources from the Baroque, eds. John Law and Evelyn Ruppert, Manchester: Mattering Press, 242-265.

Mosko, Mark S. 2005. "Introduction: A (Re)Turn to Chaos." In On the Order of Chaos: Social Anthropology and the Science of Chaos, eds. Mark S. Mosko and Frederick H. Damon, New York: Berghahn Books, 1-46.

Nagashima, Fukutarō 永島福太郎 (ed.). 1985a. “Kasuga Ōmiya Wakamiya gosairei no zu” 春日大宮若宮御祭礼図. In Kasuga (Shintō taikei:Jinjahen 13) 春日 (神道大系神 社編13) Tokyo: Shintō Taikei Hensankai, 289-436.

Nagashima, Fukutarō 永島福太郎 (ed.). 1985b. “Wakamiya Saireiki” 若宮祭禮記. In Kasuga (Shintō taikei: Jinjahen 13) 春日 (神道大系神社編13) Tokyo: Shintō Taikei Hensankai, 437-454.

Nagashima, Fukutarō 永島福太郎, Kasanoin Chikatada 花山院親忠, Misumi Haruo 三 隅治雄, Kasagi Kan'ichi 笠置㑆一 and Kojima Kenjirō 児島建次郎 (eds.). 1991. Inori no mai: Kasuga Wakamiya Onmatsuri 祈りの舞春日若宮おん祭. Osaka: Tōhō Shuppan.

Naraken Kyōikukai 奈良県教育会 (ed.). 1987. “Wakamiya” 若宮. In Yamato shiryō Vol. 1 大和志料1, Tokyo: Kadokawa Shoten, 137-140.

Nelson, Steven G. 2008. "Court and Religious Music (1): History of gagaku and shōmyō." In The Ashgate Research Companion to Japanese Music, eds. Alison McQueen Tokita and David W. Hughes, Aldershot: Ashgate, 35-48.

Ōhigashi, Nobukazu 大東延和. 1982. “Onmatsuri no rekishi” おん祭の歴史. In Kasuga Wakamiya Onmatsuri no shinji geinō 春日若宮おん祭の神事芸能, eds. Kasuga Taisha 春日大社 and Kasuga Kogaku Hozonkai 春日古楽保存会, Nara: Kasuga Taisha, 8-14.

Orikuchi, Shinobu 折口信夫. 1967. “Kasuga Wakamiya Onmatsuri no kenkyū” 春日若 宮おん祭の研究. In Orikuchi Shinobu zenshū 折口信夫全集, Vol. 17, ed. Kokugakuin Daigaku Origuchi Hakushi Kinen Kodai Kenkyūjo 国学院大学折口博士記念古代研 究所, Tokyo: Chūō Kōronsha, 278-292.

Plourde, Lorraine. 2014. "Distraction, Noise and Ambient Sounds in Tokyo." In Sound, Space and Sociality in Modern Japan, eds. Joseph D. Hankins and Carolyn S. Stevens, New York: Routledge, 71-88.

Plourde, Lorraine. 2017. "Sonic Air-Conditioning: Muzak as Affect Management for Office Workers in Japan." The Senses and Society 12(1): 18-34.

Plourde, Lorraine. 2019. Tokyo Listening: Sound and Sense in a Contemporary City. Middletown: Wesleyan University Press. 
Plutschow, Herbert. 1996. Matsuri: The Festivals of Japan. Richmond: Japan Library.

Rambelli, Fabio. 2007. Buddhist Materiality: A Cultural History of Objects in Japanese Buddhism. Stanford: Stanford University Press.

Rambelli, Fabio. 2013. A Buddhist Theory of Semiotics: Signs, Ontology, and Salvation in Japanese Esoteric Buddhism. New York: Bloomsbury.

Riedel, Friedlind. 2019a. “Atmosphere." In Affective Societies: Key Concepts, eds. by Jan Slaby and Christian von Scheve, London: Routledge, 85-95.

Riedel, Friedlind. 2019b. "Atmospheric Relations: Theorising Music and Sound as Atmosphere." In Music as Atmosphere: Collective Feelings and Affective Sounds, eds. Friedlind Riedel and Juha Torvinen, New York: Routledge, 1-42.

Riedel, Friedlind, and Juha Torvinen (eds.). 2019. Music as Atmosphere: Collective Feelings and Affective Sounds. New York: Routledge.

Roquet, Paul. 2016. Ambient Media:Japanese Atmospheres of Self. Minneapolis: University of Minnesota Press.

Schieffelin, Edward L. 2006. "Participation." In Theorizing Rituals: Issues, Topics, Approaches, Concepts, eds. Jens Kreinath, Joannes A.M. Snoek, and Michael Stausberg, Leiden: Brill, 615-627.

Schnell, Scott. 1999. The Rousing Drum: Ritual Practice in a Japanese Community. Honolulu: University of Hawai'i Press.

Slaby, Jan, and Christian von Scheve (eds.). 2019. Affective Societies: Key Concepts. London and New York: Routledge.

Sørensen, Jørgen Podemann. 2006. "Efficacy." In Theorizing Rituals: Issues, Topics, Approaches, Concepts, eds. Jens Kreinath, Joannes A.M. Snoek, and Michael Stausberg, Leiden: Brill, 523-531.

Stewart, Kathleen. 2011. "Atmospheric Attunements." Environment and Planning D: Society and Space 29(3): 445-453.

Strathern, Marilyn. 2004. Partial Connections. Lanham: AltaMira Press.

Teeuwen, Mark, and Fabio Rambelli. 2003. "Introduction. Combinatory Religion and the Honji Suijaku Paradigm in Pre-Modern Japan." In Buddhas and Kami in Japan: Honji Suijaku as a Combinatory Paradigm, eds. Mark Teeuwen and Fabio Rambelli, New York: Routledge, $1-52$.

Terauchi, Naoko 寺内直子. 2011. Gagaku o kiku: Hibiki no niwa e no izanai 雅楽を聴<一 響きの庭への誘い. Tokyo: Iwanami Shoten.

Terauchi, Naoko. 2013. "An Alternative Gagaku Tradition: The Garyōkai and Modern Osaka." In Music, Modernity and Locality in Prewar Japan: Osaka and Beyond, eds. Hugh De Ferranti and Alison McQueen Tokita, Aldershot: Ashgate, 173-19o.

Terauchi, Naoko. 2016. "Ancient and Early Medieval Performing Arts." In A History of Japanese Theatre, ed. Jonah Salz, New York: Cambridge University Press, 4-19.

Thornbury, Barbara E. 1997. The Folk Performing Arts: Traditional Culture in Contemporary Japan. Albany: State University of New York Press. 
Tsuji, Zen'nosuke 辻善之助 (ed.). 1965. Daijōin jisha zōjiki 大乘院寺社雜事記. 12 Vols. Tokyo: Kadokawa Shoten.

Tyler, Royall. 199o. The Miracles of the Kasuga Deity. New York: Columbia University Press.

Tyler, Susan C. 1992. The Cult of Kasuga Seen through Its Art. Ann Arbor: Center for Japanese Studies, University of Michigan.

Wagner, Roy. 1991. "The Fractal Person." In Big Men and Great Men: Personifications of Power in Melanesia, eds. Maurice Godelier and Marilyn Strathern, Cambridge: Cambridge University Press, 159-173.

Wetherell, Margaret. 2012. Affect and Emotion: A New Social Science Understanding. Los Angeles: SAGE.

White, Daniel. 2017. “Affect: An Introduction." Cultural Anthropology 32(2): 175-18o.

Yamamichi, Kōzō 山道興造. 1991. "Eizō Kaisetsu: Kasuga Wakamiya Onmatsuri” 映像 解説-春日若宮おん祭り. In Chūsei no sairei: Chūō kara chihōe (Taikei Nihon rekishi to geinō: Oto to eizō to moji ni yoru) 中世の祭礼中央から地方一 (大系日本歴史と芸 能一音と映像と文字による). Vol. 4, eds. Amino Yoshihiko 網野善彦 et al., Tokyo: Heibonsha, 157-174.

Yamato Geinō Konwakai 大和芸能懇話会 (ed.). 2015. Onmatsuri no hirogari おん祭の 広がり. Nara: Kasuga Wakamiya Onmatsuri Hozonkai.

Yasuda, Tsuguo 安田次郎. 2001. Chūsei no Kōfukuji to Yamato 中世の興福寺と大和. Tokyo: Yamakawa. 